\title{
Desafios da preservação do Patrimônio Arquitetônico Industrial na Bahia: o caso da Península de Itapagipe
}

\author{
Dossier De Pesquisa : PATRIMÔNIO Industrial no Norte E NoRdeste do BRASIL
}

\section{Aline de Carvalho Luther}

Professora da Faculdade de Arquitetura da Universidade Federal da Bahia. Arquiteta e Urbanista, Doutoranda do Programa de Pós-Graduação em Arquitetura e Urbanismo da Universidade Federal da Bahia. Salvador [BA] Brasil. <alinemc@ufba.br>

\section{Resumo}

Este texto pretende abordar a questão da preservação do patrimônio industrial na Bahia, analisando mais especificamente o caso da Península de Itapagipe. Inicia-se pela compreensão do cenário do patrimônio industrial no mundo e no Brasil e definição do campo do patrimônio industrial, contextualizando, a seguir, o cenário baiano. Ao final, o caso do patrimônio arquitetônico industrial da Península de Itapagipe é abordado, entendendo-se a atual situação dos edifícios e da preservação destes exemplares, relacionandoo com o contexto baiano.

\section{Palavras-chave}

Patrimônio industrial. Preservação. Península de Itapagipe.

\section{Challenges for preservation of Industrial Architectural Heritage in Bahia [Brazil]: the "Peninsula of Itapagipe" case}

\begin{abstract}
This text intends to approach the issue of the industrial heritage preservation in Bahia, analysing more specifically the case of the Peninsula of Itapagipe. It begins by understanding the scenario of industrial heritage in the world and in Brazil and defining the field of industrial heritage, contextualizing, next, the scenario of Bahia. In the end, the case of the industrial architectural heritage of the Itapagipe Peninsula is approached, understanding the current situation of the buildings and the preservation of these specimens, relating it to the context of Bahia.
\end{abstract}

\section{Keywords}

Industrial heritage. Preservation. Peninsula of Itapagipe. 


\section{Introdução}

O reconhecimento e a preservação do patrimônio industrial ainda são incipientes na Bahia, refletindo o cenário brasileiro, como observou a professora Esterzilda Berenstein de Azevedo em 2010, quando afirmou que "as pesquisas e a preservação do patrimônio industrial no Brasil são ainda incipientes, e seu campo teórico, metodológico e prático para o conhecimento sobre o patrimônio industrial está ainda disperso em esforços isolados e pouco difundidos" (Azevedo, 2010, p.18). Diversos estudos são realizados dentro do ambiente acadêmico, porém estes ainda não refletem nas políticas e práticas preservacionistas.

A Península de Itapagipe, localizada na cidade de Salvador, abrigou grande parte das indústrias implantadas na Bahia desde o início da industrialização no Brasil até a criação de novos centros industriais na segunda metade do século XX. A presença da indústria na península remete ao período da fundação da cidade pelos portugueses, abrigando olarias, estaleiros, engenhos e alambiques. Foi o maior centro industrial da cidade de Salvador durante o período compreendido entre finais do século XIX e meados do século XX, mantendo até os dias atuais diversos remanescentes da arquitetura industrial, que se encontram ameaçados, apresentando perdas contínuas.

Este artigo tem como objetivo entender a preservação do patrimônio arquitetônico industrial na Bahia, aprofundando o estudo no caso da Península de Itapagipe. 0 conteúdo deste artigo é parte da dissertação de mestrado finalizada em 20121, trazendo, porém, um enfoque maior na questão da preservação e do reconhecimento do patrimônio industrial na Bahia, e atualizado as informações com dados mais atuais.

\section{0 patrimônio industrial e sua preservação na Bahia}

A preservação do patrimônio industrial na Bahia é um processo recente, iniciado no século XX. Para contextualizar o início da preservação deste patrimônio na Bahia, é interessante entender brevemente o seu desenvolvimento na Europa e no Brasil, contextualizando-o, além de definir o campo do patrimônio industrial.

\subsection{0 patrimônio industrial e suas origens}

0 início da preocupação pelos temas ligados à preservação do patrimônio industrial remete a finais do século XVIII, na França, de forma pioneira e pontual, como reação à demolição de vários edifícios pelo chamado "vandalismo revolucionário"2 (Kühl, 2008). No século XIX esta preocupação apareceu também em países como Suécia, Portugal e Inglaterra, porém de forma embrionária. A expressão "arqueologia industrial" surgiu final do século XIX no texto intitulado "Arqueologia Industrial Portuguesa: Os Moinhos" de Francisco de Souza Viterbo, arqueólogo e escritor. Neste artigo o autor questionava: "Existe a archeologia da arte, porque não há de existir a archeologia da industria?"3 (Viterbo, 1896, p. 193), mostrando o interesse em documentar os processos, instrumentos e aparelhos adotados, preocupando-se não apenas pelo processo material, mas também pelo imaterial. Apesar do surgimento precoce, nem mesmo em Portugal o tema teve repercussão naquele momento (Kühl, 2008).

No início da década de 1950, a expressão arqueologia industrial (industrial archaeology) reapareceu na Inglaterra, quando foi utilizada pelo professor da Universidade de Birmingham, Donald Dudley4, porém apenas no ano de 1955 consta pela primeira vez em uma publicação inglesa, no artigo de Michael Rix para The Amateur Historian (Kühl, 2008), "[...] que deu à arqueologia industrial,

\footnotetext{
${ }^{1}$ Luther, A. d. (2012). Patrimônio Arquitetônico Industrial da Península de Itapagipe: um estudo para a preservação. Dissertação de Mestrado, Universidade Federal da Bahia, Faculdade de Arquitetura e Urbanismo, Salvador.

2 Referindo-se às devastações e saques praticados no período que se seguiu à Revolução Francesa.

${ }^{3}$ Neste trabalho será mantida a grafia original dos documentos nas citações.

4 Kenneth Hudson diz que o termo foi inventado por Donald Dudley (Hudson, 1979), desconsiderando as primeiras ocorrências no século XIX.
} 
tanto um nome como um campo de estudo, para o mundo"5 (Hudson, 1979), sem definir, porém, o campo de estudo e assumindo que a arqueologia industrial seria restrita ao período da Revolução Industrial (Hudson, 1979). A partir de então a expressão se popularizou na Inglaterra, sendo utilizada até os dias atuais.

Em 1959 a primeira conferência nacional sobre Arqueologia Industrial foi convocada pelo Conselho Britânico de Arqueologia (Council for British Archaeology - CBA), resultando na chamada para a realização de um levantamento nacional de monumentos industriais para identificar e avaliar sítios industriais históricos merecedores de proteção. Naquele momento, com a criação do Comitê de Arqueologia Industrial (Industrial Archaeology Committee), a arqueologia industrial foi reconhecida como disciplina 6 .

Estudos sistemáticos sobre o patrimônio industrial e a sua preservação iniciaram-se na Inglaterra ainda por volta do final da década de 1950, e o tema foi consolidando-se e ganhando espaço, especialmente após a sensibilização da população com a demolição de diversos exemplares arquitetônicos importantes do processo de industrialização, como o Pórtico Dórico da Estação Euston, em Londres, em 1962. Esse processo chegou com mais força inicialmente no cenário europeu, e em seguida espalhou-se pelo resto do mundo. Apesar de existir protestos e mobilização para a manutenção dos exemplares significativos da arquitetura industrial, a partir de então, muitos outros ainda foram demolidos?.

Um grande problema encontrado pelas antigas instalações industriais é que estas ocupavam, e ainda ocupam, extensas áreas em centros urbanos, geralmente privilegiadas em relação à facilidade de acesso e transporte. Com a obsolescência de grande parte dessas instalações e valorização das localizações onde estão implantadas, seus terrenos passaram a ser áreas de grande interesse para a renovação urbana. Hoje várias das instalações industriais, como afirma Rufinoni (2014, p. 116), “[...] foram substituídas por edifícios mais modernos ou se configuram como uma representativa reserva de área urbana, logo ameaçada pelo crescimento das cidades e valorização do solo". Essas instalações sofrem, desta forma, com a grande pressão da especulação imobiliária, que torna ainda mais árduo o processo para a preservação dos exemplares mais representativos.

Os estudos e esforços para o conhecimento, e reconhecimento, do patrimônio industrial fizeram com que fossem criados grupos, geralmente chamados de sociedade, voltados para tal tarefa, como a Sociedade de Arqueologia Industrial da Região de Manchester (The Manchester Region Industrial Archaeology Society - MRIAS), fundada em 19648, a Sociedade Industrial Arqueológica Bristol (Bristol Industrial Archaeological Society - BIAS), organizada em 19679, a Sociedade de Arqueologia Industrial da Grande Londres (The Greater London Industrial Archaeology Society GLIAS), do ano de 196810, a Sociedade de Arqueologia Industrial (The Society for Industrial Archeology - SIA), organização Norte Americana fundada em 197111, entre outros.

O levantamento do patrimônio industrial teve seu início efetivamente no ano de 1962, após a chamada feita pelo CBA em 1959 para a realização do levantamento nacional de monumentos industriais, com a criação do Levantamento de Monumentos Industriais (The Industrial Monuments

\footnotetext{
5 Todas as traduções foram feitas pela autora, aparecerão traduzidas no texto e o original em nota de rodapé, como segue: "[...] which gave industrial archaeology, both as a name and as a range of study, to the world." (Hudson, 1979, p.1).

6 Informações contidas no site do Council for British Archaeology: <new.archaeologyuk.org>. Acesso em 17/06/2018.

7 Para maiores informações sobre a Estação Euston e outros edifícios emblemáticos do período ver Kühl, 1998 e 2008 e Rufinoni, 2004.

8 Informação obtida no website da The Manchester Region Industrial Archaeology Society: <www.mrias.co.uk>. Acesso em 27/06/2018.

9 Informação obtida no website da Bristol Industrial Archaeological Society: <www.b-i-a-s.org.uk>. Acesso em $27 / 06 / 2018$.

${ }^{10}$ Informação obtida no website da The Greater London Industrial Archaeology Society: <www.glias.org.uk>. Acesso em $27 / 06 / 2018$.

11 Informação obtida no website da The Society for Industrial Archeology: <www.sia-web.org>. Acesso em $27 / 06 / 2018$.
} 
Survey) 12. "Embora em grande parte financiado pelo Ministério13, o Levantamento foi gerido pela CBA e aquele grupo procurou envolver suas sociedades arqueológicas constituintes no exercício de identificar e documentar instalações industriais." 14 (Falconer, 2006, p. s/n). 0 encorajamento aos grupos entusiastas locais constituiu uma rede de sociedades arqueológicas industriais regionais, cujos trabalhos serviram e continuam servindo de apoio ao Levantamento de Monumentos Industriais ${ }^{15}$. A maioria dos autores que escreveram sobre o tema nos anos 1960 e 1970 fazia parte destes grupos.

No ano de "[...] 1965, o Ancient Monuments Board decide reconhecer a tipologia industrial digna de proteção, da mesma forma que outros sítios monumentais e arqueológicos tradicionais" (Rufinoni, 2004, p. 116). Esta necessidade de, ao menos, registrar este patrimônio ameaçado regeu, inicialmente, a atuação do Levantamento de Monumentos Industriais e foi gradualmente alcançando muitos outros países, tanto na Europa como em todo o mundo, que desenvolveram e continuam desenvolvendo inventários específicos.

Em 1978 foi criado o Comitê Internacional para a Conservação do Patrimônio Industrial (The International Committee for the Conservation of the Industrial Heritage - TICCIH), durante o $3^{\circ}$ Congresso Internacional para a Conservação dos Monumentos Industriais, em Estocolmo, para tratar da conservação do patrimônio industrial. Este comitê realiza importantes conferências, que contam com pesquisadores de diversos países, e firmou-se como o principal organismo internacional de preservação do patrimônio industrial. Em julho de 2003, na cidade de Nizhny Tagil, Rússia, foi firmada a carta que leva o nome da cidade (Carta de Nizhny Tagil sobre o Patrimônio Industrial), durante a Conferência de 2003 do TICCIH, voltada exclusivamente para a preservação do patrimônio industrial16. 0 tema da conservação do patrimônio industrial teve a sua inserção na discussão das mesas temáticas apenas em 1999, com a assembleia Mundial do Conselho Internacional de Monumentos e Sítios (International Council on Monuments and Sites ICOMOS), ocorrida no México (Vichnewski, 2004).

É interessante observar que a arqueologia industrial é um estudo que não nasceu exclusivamente da elite para a elite, como era comum em meados do século XX, tendo participação das classes populares, de trabalhadores que buscavam resgatar a memória do seu ofício, de pessoas que fizeram parte do processo da industrialização, em diversos níveis, não tendo um enfoque na vida e bens da elite (apesar da sua produção ter sido financiada por ela). Em 1972 R. A. Buchanan escreveu que a "Arqueologia industrial tornou-se um assunto popular nos últimos 10 anos, pois oferece algo para todos. Ela está preocupada com esse patrimônio comum do povo da Grã-Bretanha, seu passado em comum, e, em especial com a excepcional realização nacional dos últimos dois séculos"17 (Buchanan, 1972, p. 19). A arqueologia industrial trabalha principalmente com edifícios e maquinário provenientes da indústria e dos seus processos, muitas vezes considerados sem grande valor estético, porém de grande valor para a comunidade e aqueles que fizeram parte da sua história. Possivelmente o grande interesse da população em recuperar o patrimônio industrial provém deste fator. Este interesse popular fez com que rapidamente crescesse o número de grupos dedicados ao estudo da arqueologia industrial, chegando a 85 , no ano de 1979, dedicados à pesquisa e conservação da indústria britânica (García García \& Rivas Badillo, 2007).

\footnotetext{
12 Falconer, 2006.

13 Quando Falconer (2006) cita o Ministério, refere-se ao Ministério de Edifícios Públicos e Obras (Ministry of Public Buildings and Works), departamento do Governo do Reino Unido.

14 "Though largely funded by the Ministry the Survey was managed by the CBA and that body sought to involve its constituent archaeological societies in the exercise of identifying and documenting industrial sites." (Falconer, 2006, p. s/n).

15 Para mais informações sobre o processo de proteção do patrimônio industrial na Grã-Bretanha ver Falconer, 2006.

16 Informações disponíveis no website do Comitê Brasileiro para a Preservação do Patrimônio Industrial TICCIH Brasil: <www.patrimonioindustrial.org.br>. Acesso em 27/06/2018.

17 "Industrial archaeology has become a popular subject in the last ten years because it offers something to everybody. It is concerned with that common heritage of the people of Britain, their shared past, and in the particular with the outstanding national achievement of the last two centuries." (Buchanan, 1972, p. 19).
} 
O uso da expressão "arqueologia industrial" e sua definição geraram diversos debates. Conforme Beatriz Kühl: "Houve esforços sistemáticos que se estenderam dos anos 1950 a 1980 para definir o tema e suas implicações teórico-metodológicas [...]" (Kühl, 2008, pp. 44-45). Muitas questões foram colocadas em relação: ao uso da palavra arqueologia para tratar sobre o tema, já que em muitos casos não se utilizavam os métodos da arqueologia "tradicional" (como, por exemplo, as escavações); ao recorte cronológico que deveria ser abrangido; e aos objetos de estudo da disciplina (Kühl, 2010).

Não nos ateremos a este processo evolutivo da definição do termo arqueologia industrial 18 . Utilizaremos aqui as definições adotadas na Carta Nizhny Tagil que, segundo a professora da FAU/USP Beatriz Kühl, "[...] é uma síntese amadurecida dessas definições feitas ao longo de várias décadas, transparecendo uma visão abrangente do problema [...]" (Kühl, 2010, p. 25). A Carta define o patrimônio industrial como os vestígios da cultura industrial possuidores de valor histórico, social, arquitetônico, tecnológico ou científico, podendo ser estes edifícios, fábricas, armazéns, oficinas, locais de processamento, centros de produção, transmissão e utilização de energia, maquinaria, meios de transporte, suas estruturas e infraestruturas, e locais onde desenvolveram-se atividades sociais relacionadas à indústria, como habitações, locais de culto e de educação (TICCIH, 2003) ${ }^{19}$.

A arqueologia industrial é definida pela Carta como "[...] um método interdisciplinar que estuda todos os vestígios, materiais e imateriais, os documentos, os artefactos, a estratigrafia e as estruturas, as implantações humanas e as paisagens naturais e urbanas, criadas para ou por processos industriais." (TICCIH, 2003, p. 03), que se utiliza das formas de investigação mais adequadas para aumentar a compreensão do passado e do presente industrial. 0 período histórico delimitado é aquele de maior importância ao estudo da disciplina, ou seja, desde os inícios da Revolução industrial até a atualidade, “[...] sem negligenciar as suas raízes pré e proto-industriais." (TICCIH, 2003, p. 3).

A expressão arqueologia industrial predomina em diversos países. Em outros, como é o caso do Brasil, predomina a expressão patrimônio industrial20. Muitas vezes estas expressões são utilizadas como sinônimos, de forma errônea, desconsiderando-se as diferenças semânticas dos dois termos. A expressão patrimônio industrial refere-se, conforme a Carta de Nizhny Tagil, aos vestígios da cultura industrial e locais onde desenvolveram-se atividades sociais relacionadas à indústria. Já a arqueologia industrial apresenta-se como um campo mais amplo, voltando seus esforços a todo o legado da industrialização.

Em relação a esta diferença entre arqueologia industrial e patrimônio industrial a professora Beatriz Kühl faz a seguinte observação:

De todo modo, multiplicam-se os estudos vinculados ao tema e, em alguns países, predomina o emprego da expressão "arqueologia industrial" e, em outros, "patrimônio industrial". A arqueologia industrial volta-se ao estudo, análise e registro de formas de industrialização do passado - mesmo quando desapareçam os testemunhos materiais - e, por vezes, quando reconhecido o interesse como bem cultural, à sua preservação. Quando se fala em patrimônio industrial, pressupõe-se que tenham sido feitos esses estudos - que devem ser multidisciplinares - e que se tenham identificado os bens que possuem o interesse para a preservação; a "arqueologia industrial" volta seus esforços a todo o legado da industrialização, seja ele considerado bem cultural ou não. Na prática, porém, as ex-pressões têm sido usualmente empregadas como sinônimos (Kühl, 2008, p. 45).

\footnotetext{
18 Para um aprofundamento sobre este assunto ver Kühl, 1998 e 2008 e Rufinoni, 2004.

${ }^{19}$ A versão em português da Carta de Nizhny Tagil, cuja tradução é de responsabilidade da Associação Portuguesa para o Património Industrial (APPI), pode ser encontrada no seguinte link: <http://www.mnactec.cat/ticcih/pdf/ NTagilPortuguese.pdf $>$. Acesso em 06/02/2012.

20 A professora do IFCH/UNICAMP, Cristina Meneguello, em seu artigo de 2011, utiliza a expressão "patrimônio industrial" justificando (na Nota de rodapé 2): “Opto nesse texto pela utilização da expressão patrimônio industrial, mais corrente no Brasil, em detrimento de arqueologia industrial.” (Meneguello, 2011, p. 1821).
} 
No Brasil devemos ainda considerar a falta de reconhecimento da própria disciplina arqueologia. Poucos estudos arqueológicos são realizados e, muitas vezes, mesmo em casos onde são extremamente importantes e necessários, são ignorados. Não se pode diferenciar o que é a arqueologia e o que é o patrimônio sem ao menos entender o que cada qual significa e suas abrangências.

Como foi dito na introdução, trataremos neste trabalho mais especificamente da arquitetura industrial. Muitos não consideram esta arquitetura digna de conservação, por não reconhecer nela um valor que justifique a imobilização de uma área que poderia receber um edifício que valorizasse muito mais o sítio onde essa está alocada. Sobre esta questão Garcia e Rivas afirmam que:

A arqueologia industrial é pouco atrativa para a vista, em geral não é considerada bela esteticamente, a sociedade atual mostra um amplo desinteresse, mas não devemos esquecer que cumpriu com uma função social em sua época de apogeu. A arqueologia industrial possui um desenho e uma série de valores arquitetônicos, tecnológicos, sociológicos e paisagísticos que a converte em um documento de primeira magnitude para conhecer as indústrias e a história de uma sociedade ${ }^{21}$ (García García \& Rivas Badillo, 2007, p. 67).

Felizmente temos, hoje, muitos estudos que comprovam a importância da arqueologia, do patrimônio e da arquitetura industrial. Compreende-se que a partir deles podemos apreender diversos processos, como a formação de grandes áreas urbanas, de grupos que fazem parte do contexto humano, social e cultural, assim como ampliar e aprofundar análises históricas, políticas, sociais e econômicas. $\mathrm{O}$ interesse pela arqueologia industrial vem aumentando e um grande número de países já se preocupa com o seu patrimônio, realizando inventários e protegendo os seus exemplares. Muitos estudiosos se dedicam ao estudo do tema em todo o mundo, ainda com graus diferentes de mobilização em cada um dos países. A Inglaterra ainda é o país que tem a maior discussão no campo da arqueologia industrial e da preservação do seu patrimônio, inclusive devido à sua história. Pode ser observado um progresso constante na discussão do tema, sendo um assunto bastante vivo, tendo relações com os mais diversos campos de conhecimento, como, por exemplo, os campos da história, da antropologia, da sociologia, da arquitetura, do restauro, entre outros.

\subsection{0 patrimônio industrial no Brasil}

A proteção de um bem relativo ao patrimônio industrial ocorreu precocemente no Brasil, porém com uma significação bem diferente da do contexto europeu. Em 1938 o Instituto do Patrimônio Artístico Nacional (IPHAN) tombou as ruínas da primeira fábrica de ferro do Brasil22, a Fábrica de Ferro Patriótica, localizadas no Distrito de São Julião, em Ouro Preto, cuja construção deu-se entre os anos de 1811 e 1812. Este fato ocorreu apenas dois anos após a criação do IPHAN (chamado no então de SPHAN - Serviço do Patrimônio Histórico e Artístico Nacional). Naquele momento ainda não se pensava na questão do patrimônio industrial e o SPHAN tinha o seu principal foco no patrimônio relativo ao período colonial, "[...] ainda dentro do reconhecimento promovido pelos modernistas da imagem de patrimônio nacional associada às Minas Gerais e à riqueza proporcionada pela exploração do ouro [...]" (Meneguello, 2011, p. 1824), sendo, nos tombamentos, a prioridade "[...] dada aos remanescentes da arte colonial brasileira [...] identificados pelas classes médias afluentes (em que se incluíam os imigrantes que enriqueciam com a industrialização) com um passado arcaico, primitivo, e com a presença portuguesa [...]" (Fonseca, 2005, p. 107).

Com o foco do SPHAN em um patrimônio nacional restrito, foram desconsideradas as outras manifestações artísticas que representavam a dominação cultural estrangeira, como os estilos eclético, neogótico, neoclássico, etc., e a modernização vinda com a Primeira República. Neste grupo relegado insere-se a nascente indústria e sua nova arquitetura, com muitos elementos

\footnotetext{
21 "La arqueología industrial es poco atractiva para la vista, en general no es considerada bella estéticamente, la sociedad actual muestra un amplio desinterés, pero no hay que olvidar que cumplió con una función social en su época de apogeo. La arqueología industrial posee un diseño y una serie de valores arquitectónicos, tecnológicos, sociológicos y paisajísticos que la convierte en un documento de primera magnitud para conocer las industrias y la historia de una sociedad" (García García \& Rivas Badillo, 2007, p. 67).

22 Registrado no Livro Histórico, Inscrição: 072, Data: 30-6-1938, Processo:0031-T-38. Fonte: Site do Arquivo Noronha Santos: <http://www.iphan.gov.br/ans.net/>. Acesso em 30/06/2018.
} 
importados e, principalmente, dentro da arquitetura eclética. Uma grande parte destes exemplares arquitetônicos que não se enquadrava na ideia de patrimônio nacional do IPHAN se perdeu.

Na década de 1940 foram tombados alguns exemplares da agroindústria açucareira do período colonial, também associados ao pensamento inicial do IPHAN, em um momento que esta forma de produção já havia perdido a sua representatividade no nordeste do país. Na maioria dos casos foram tombados os edifícios residenciais e religiosos, entretanto podemos destacar o tombamento do Engenho Matoim (sobrado e fábrica de açúcar)23, em 1943, e do Engenho Freguesia (sobrado, fábrica de açúcar e Capela de Nossa Senhora da Piedade)24, em 1944, atual Museu Wanderley Pinho ou do Recôncavo, ambos na cidade de Candeias - BA; "foram protegidos os dois primeiros exemplares de arquitetura industrial no Brasil, através da inclusão, nestes tombamentos, não apenas dos edifícios residenciais e religiosos como também das respectivas fábricas de açúcar." (Andrade Junior, 2011, p. 04).

Porém, esses dois tombamentos dos remanescentes das fábricas dos engenhos foram realmente exceções. No ano de 1943 também foi tombado o Solar do Unhão 25 , complexo agroindustrial do mesmo tipo dos engenhos de açúcar, localizado na cidade de Salvador - BA, que funcionou como fábrica de rapé entre 1816 e 1926. Em relação aos engenhos, em 1963 foram tombadas as ruínas do Engenho de São Jorge dos Erasmos 26 , localizado em Santos - SP, “[...] o único exemplar conhecido da primeira tentativa oficial de exploração açucareira no Brasil." (Arquivo Noronha Santos. Acesso em 30/06/2018). Deve ser ressaltado que nem todos consideram os engenhos tombados em suas contagens de edifícios tombados no país. Neste trabalho estes são considerados como parte das raízes da industrialização no Brasil, porém sem desconsiderar o contexto e a motivação destes tombamentos. Sobre esta desconsideração dos engenhos como parte do universo industrial a historiadora Marly Rodrigues diz:

A Carta de Nizhny Tagil, embora observando que o período de maior relevo para os estudos do patrimônio industrial inicia-se na segunda metade do século XVIII, recomenda que não se negligencie o estudo das raízes pró e protoindustriais apoiado no estudo das técnicas de produção, englobadas pela história da tecnologia. O Engenho de São Jorge dos Erasmos, porém, nem sempre é considerado representativo do universo industrial, possivelmente por tratar-se de ruínas. Considera-se ação pioneira do Iphan, no campo da preservação do patrimônio industrial, o tombamento, realizado em 1964, da Real Fábrica de Ferro de Ipanema, implantada em 1810 (Rodrigues, 2010, p. 35).

Em 1964, concomitantemente com a movimentação que ocorria na Europa em relação à proteção do patrimônio industrial, o IPHAN tombou o conjunto formado pelos remanescentes da Real Fábrica de Ferro de São João de Ipanema27, em Iperó, São Paulo, fundada em 1810 e custeada pelo Estado a maior parte do tempo. No site do Arquivo Noronha Santos encontramos na descrição da fábrica o seguinte texto:

Remanescentes de arqueologia industrial do primeiro complexo funcionante para exploração e fabricação do ferro no Brasil. Os esforços para a implantação de uma siderurgia, concentraram-se em Ipanema, a partir de 1818, com a vinda de artesãos e mestres europeus, entre os quais Varnhagem, cujo o filho, importante historiador, ali nasceu.

\footnotetext{
23 Registrado no Livro Histórico, Inscrição: 217, Data: 6-9-1943, Processo: 0323-T. Fonte: Site do Arquivo Noronha Santos: <http://www.iphan.gov.br/ans.net/>. Acesso em 30/06/2018.

24 Registrado nos Livros Histórico e de Belas Artes, Inscrição: 237 e 304, respectivamente, Data: 14-9-1944, Processo: 0322-T-43. Fonte: Site do Arquivo Noronha Santos: <http://www.iphan.gov.br/ans. net/>. Acesso em 30/06/2018.

25 Registrado nos Livros Histórico e de Belas Artes, Inscrição: 220 e 288-A, respectivamente, Data: 16-9-1943, Processo: 0279-T. Fonte: Site do Arquivo Noronha Santos: <http://www.iphan.gov.br/ans.net/>. Acesso em 30/06/2018.

${ }^{26}$ Registrado no Livro Histórico, Inscrição: 360, Data: 2-7-1963, Processo: 0678-T-62. Fonte: Site do Arquivo Noronha Santos: <http://www.iphan.gov.br/ans.net/>. Acesso em 30/06/2018. Segundo Marli Rodrigues (2010), cinco anos depois foi inscrito também no Livro de Belas Artes, Inscrição 488 (não consta no site do Arquivo).

27 Registrado no Livro Histórico, Inscrição: 376-B, Data: 24/09/1964, Processo:0727-T-64. Fonte: Site do Arquivo Noronha Santos: <http://www.iphan.gov.br/ans.net/>. Acesso em 30/06/2018.
} 
Estas instalações funcionaram até o final do século XIX, produzindo grades, equipamento agrícola e armas brancas ("Site" do Arquivo Noronha Santos. Acesso em 30/06/2018).

Percebe-se que, neste momento, a arquitetura industrial já é reconhecida como um bem de valor, e o tombamento da Real Fábrica de Ferro de São João de Ipanema poderia antever uma política para a preservação do patrimônio industrial. Porém este tombamento ocorreu de forma isolada e incipiente, e os órgãos de preservação nacionais não desenvolveram o tema do patrimônio e da arqueologia industrial. Deve-se observar que após o tombamento a fábrica recebeu apenas ações de restauro pontuais, que visaram somente a preservação dos edifícios em pior estado de conservação, já que a fábrica se encontrava em um estado de ruína bastante avançado na década de 1960 (Santos, 2009). Após estas ações pontuais a fábrica “[...] permaneceu por muitos anos abandonada, até que, em 2005, a Usiminas patrocinou o seu projeto de restauração, executado pela Arruda Associados, com apoio da Associação Brasileira de Metalurgia (ABM)." (Gomes, 2007, p. 5).

Algo que deve ser observado, porém, é que tanto o processo de industrialização no Brasil, que pode ser considerado a partir de meados do século XIX, quanto o processo de desindustrialização, nas décadas de 1980 e 1990, ocorreram tardiamente, demorando a aparecer os sintomas da destruição apresentados pela Europa a partir de meados do século XX. Desta forma, dificilmente o pensamento vigente na Europa da década de 1960 se desenvolveria no Brasil no mesmo momento em que se desenvolveu nesse continente. Segundo a professora Cristina Meneguello:

Diferente do que aconteceu na Europa, que sofreu um processo de desindustrialização vasto dos anos 1960 em diante os países da América Latina só lidaram com a necessidade de preservação do patrimônio industrial durante as últimas décadas, principalmente devido à desintegração de grandes plantas industriais e destruição de habitações, armazéns e outros símbolos do período industrial. No entanto, as marcas do trabalho dos homens, da maquinaria e das práticas cotidianas comuns dos séculos anteriores (produção de cana de açúcar e de mineração, por exemplo) desempenham um papel importante na preservação da memória28 (Meneguello, 2006, p. 1).

A preservação do patrimônio industrial nos países latino-americanos só passou a ser encarada seriamente nas últimas décadas, após a destruição de vários exemplares da arquitetura industrial e de símbolos dos séculos precedentes, como engenhos de açúcar e equipamentos relacionados à mineração (Meneguello, 2011). Desde meados da década de 1970 são realizadas pesquisas sobre o patrimônio industrial brasileiro no meio acadêmico. A professora Cristina Meneguello diz que:

Assim como ocorrera com a experiência inglesa, os primeiros a perceberem a importância desse patrimônio foram aqueles envolvidos no estudo da história da tecnologia e do maquinário, ainda na década de 1960. Progressivamente, contaram com a companhia de historiadores e arquitetos interessados nas práticas do trabalho industrial e nos vestígios arquitetônicos (Meneguello, 2011, p. 1827).

Segundo Vichnewski (2004), o estudo sobre arqueologia industrial no Brasil foi inaugurado pelo artigo sobre a fábrica São Luiz de Itu, escrito pelo historiador norte-americano Warren Dean em 1976, publicado nos Anais de História, da Universidade Estadual Paulista (UNESP). Porém existe outro estudo relativo à arqueologia industrial que pode ser considerado o inaugural sobre o tema no país. Em 1975 José Luis Pamponet Sampaio apresentou sua dissertação de mestrado cujo título é "A evolução de uma empresa no contexto da industrialização brasileira: a Companhia Empório Industrial do Norte, 1891 - 1973", abordando o crescimento da industrialização e a indústria têxtil no Brasil e na Bahia, destrinchando, por fim, diversos temas relativos à Companhia Empório.

Ainda em 1976 foi lançado pela FAU/USP o Guia para a história da técnica no Brasil Colônia, de Júlio Roberto Katinsky, refletindo a preocupação de um grupo de professores da Universidade de São Paulo

\footnotetext{
28 "Different from what happened in Europe, which suffered a vast deindustrialization process from the 1960's on, the countries in Latin America would only deal with the need for preservation of the industrial heritage during the last few decades, mainly due to the disintegration of large industrial plants and destruction of housing, warehouses and other symbols of the Industrial period. However, the marks of the work of men, the machinery and of the everyday common practices of previous centuries (sugar cane production and mining, for instance) play an important role in the preservation of memory" (Meneguello, 2006, p. 1).
} 
que pesquisavam os remanescentes das instalações de produção de bens de consumo. Podemos destacar ainda os trabalhos de Ruy Gama sobre tecnologia ("Engenho e Tecnologia", concluído em 1978 e publicado em 1983 e "A tecnologia e o trabalho na história", publicado em 1986), os trabalhos de Edgar De Decca, como "Democracia e Classe operária”, de 1978, entre outros que se seguem. Outros pesquisadores que desenvolveram o tema a partir de então e devem ser lembrados são Philip Gunn, Telma de Barros Correia, Maria Auxiliadora De Decca, Bandeira Júnior, Flávio A. Marques Saes, Francisco Foot Hardman, Milton Vargas, Murillo Marx, Odilon Nogueira de Matos, Pedro Carlos da Silva Telles, Ulpiano Bezerra de Meneses, Esterzilda B. de Azevedo, Geraldo Gomes da Silva, Xavier Maureau, Antonio Luiz de Andrade, Andrey Rosenthal Schlee (Kühl, 2008; Vichnewski, 2004; Meneguello, 2011).

Porém todos estes estudos não se refletiram no pensamento da população nem dos órgãos responsáveis pela preservação do patrimônio, onde os estudos e a proteção do patrimônio industrial no Brasil ainda dão os seus primeiros passos. Após o tombamento dos remanescentes da Real Fábrica de Ferro de São João de Ipanema passaram-se décadas até que o órgão federal tombasse outro edifício industrial, a Fábrica de Vinho Tito Silva, em João Pessoa, Paraíba, em 1984. Segundo os arquivos do IPHAN, "Seu tombamento representou uma inovação nessa área, pois não só o monumento, a maquinaria e o equipamento foram preservados, como também a técnica industrial."29 (Arquivo Noronha Santos, Acesso em 30/06/2018).

Na década de 1980, se intensificaram os tombamentos referentes à arquitetura industrial e novas categorias de bens passaram a ser abarcadas. Neste período podem-se observar os seguintes tombamentos: pórtico central e armazéns do cais do porto de Porto Alegre em 198330; Açude de Cedro em Quixadá [CE] em 198431; Caixa d'Água de Pelotas [RS], exemplar da arquitetura pré-fabricada francesa em ferro, no ano de 198432; antiga Estação Ferroviária de Lassance [MG], em 198533; Engenho do Mate, no município de Campo Largo [PR], em 198534; Fábrica de Tecidos Santa Amélia, São Luís [MA], em 198735; e Complexo Ferroviário de São João Del Rei [MG], em 198936 (Andrade Junior, 2011).

Nas duas décadas seguintes foram ainda tombados a Estação da Luz em São Paulo, em 199637, o Conjunto de Edificações da Companhia Paulista das Estradas de Ferro em Jundiaí [SP], em 200438 e a Vila Ferroviária de Paranapiacaba, no Município de Santo André (SP), em 200839, dezessete anos após uma solicitação formal de tombamento.

${ }^{29}$ Registrado no Livro Histórico, Inscrição: 495, Data: 2-8-1984, Processo: 1054-T-82. Fonte: Site do Arquivo Noronha Santos: <http://www.iphan.gov.br/ans.net/>. Acesso em 30/06/2018.

30 Registrado no Livro de Belas Artes, Inscrição: 552, Data: 19-5-1983, Processo: 1047-T-81. Fonte: Site do Arquivo Noronha Santos: <http://www.iphan.gov.br/ans.net/>. Acesso em 30/06/2018.

31 Registrado nos Livros Arqueológico, Etnográfico e Paisagístico e de Belas Artes, Inscrição: 087 e 563, respectivamente, Data: 19-7-1984, Processo: 1082-T-83. Fonte: Site do Arquivo Noronha Santos: <http://www.iphan.gov.br/ans.net/>. Acesso em 30/06/2018.

32 Registrado no Livro de Belas Artes, Inscrição: 561, Data: 19-7-1984, Processo: 1064-T-82. Fonte: Site do Arquivo Noronha Santos: <http://www.iphan.gov.br/ans.net/>. Acesso em 30/06/2018.

33 Registrado no Livro Histórico, Inscrição: 499, Data: 30-9-1985, Processo: 1143-T-85. Fonte: Site do Arquivo Noronha Santos: <http://www.iphan.gov.br/ans.net/>. Acesso em 30/06/2018.

34 Registrado nos Livros Histórico e de Belas Artes, Inscrição: 496 e 567, respectivamente, Data: 24-4-1985, Processo: 1119-T-84. Fonte: Site do Arquivo Noronha Santos: <http://www.iphan.gov.br/ans. net/>. Acesso em 30/06/2018.

${ }^{35}$ Registrado no Livro Histórico, Inscrição: 513, Data: 1-7-1987, Processo: 1144-T-85. Fonte: Site do Arquivo Noronha Santos: <http://www.iphan.gov.br/ans.net/>. Acesso em 30/06/2018.

36 Registrado nos Livros Histórico e de Belas Artes, Inscrição: 528 e 596, respectivamente, Data: 3-8-1989, Processo: 1185-T-85. Fonte: Site do Arquivo Noronha Santos: <http://www.iphan.gov.br/ans. net/>. Acesso em 30/06/2018.

37 Registrado nos Livros Histórico e de Belas Artes, Inscrição: 540 e 606, respectivamente, Data: 10-10-1996, Processo: 0944-T-76. Fonte: Site do Arquivo Noronha Santos: <http://www.iphan.gov.br/ans. net/>. Acesso em 30/06/2018.

38 Tombamento não cadastrado no Site do Arquivo Noronha Santos. Registrado no Livro de Belas Artes, Inscrição: 570, Data: 14-07-2004, Processo: 1485-T-01. Fonte: <http://portal.iphan.gov.br/portal/baixa FcdAnexo.do?id=1356>. Acesso em 30/06/2018.

39 Tombamento não cadastrado no Site do Arquivo Noronha Santos. Registrado no Livro Histórico, Inscriccão: 586, Data: 30/09/2008, Processo 1252-T-87. Fonte: <http://portal.iphan.gov.br/portal/baixa FcdAnexo.do?id=1356>. Acesso em 30/06/2018. 
Outro fator que chama a atenção em relação à arqueologia industrial no Brasil é que não houve mobilização da população para a proteção dos exemplares e nem a participação desta nos estudos realizados, restringindo-se praticamente de forma exclusiva ao meio acadêmico, maior interessado no assunto. Enquanto na Grã-Bretanha a população se manifestou, criou sociedades e buscou defender uma parte importante da história que eles fizeram parte, no Brasil a população não se mostrou atuante no estudo da sua própria história, não demonstrando grande interesse pelo patrimônio industrial e sua preservação ${ }^{40}$. Temos alguns casos de mobilização da própria população envolvida, porém com um enfoque maior no patrimônio ferroviário, especificamente, como nos casos da Associação Brasileira de Preservação Ferroviária - ABPF, da Associação Nacional de Preservação Ferroviária - ANPF, do Movimento de Preservação Ferroviária - MPF, da Associação Nacional dos Transportes Ferroviários - ANTF e da Associação Brasileira dos Operadores de Trens Turísticos - ABOTTC.

Em 1986 foi realizado em São Paulo o 1o Seminário Nacional de História e Energia, organizado pela Companhia de Força Elétrica de São Paulo (Departamento de Patrimônio Histórico da Eletropaulo). Este foi o primeiro encontro sobre o tema no Brasil. "Pode-se dizer que foi um dos primeiros congressos, no Brasil, no qual foram discutidos, em duas mesas temáticas, aspectos da arqueologia industrial no mundo e no Brasil." (Vichnewski, 2004, p. 33). Em 1997, em Campinas, o Grupo de Estudos de História da Técnica - GEHT recuperou o papel do legado da industrialização em suas reuniões e, no ano de 1998, lançou a "Declaração do GEHT em defesa das construções e instalações utilitárias", conhecida como Carta de Campinas, que apresenta grande defesa aos edifícios da industrialização e seus equipamentos, criticando a atuação dos Conselhos de Tombamento e fazendo recomendações de atuação41.

No ano de 2004, o Comitê Brasileiro para Preservação do Patrimônio Industrial (TICCIH -Brasil), versão brasileira do comitê, ligada ao internacional, iniciou a sua atuação. Desde os anos 1980 o TICCIH vinha tentando articular representantes no Brasil, devido ao interesse despertado pelos remanescentes bem conservados do patrimônio industrial, muito devido à sua industrialização tardia, com um grande número de exemplares importados, tendo sido o Brasil um dos maiores importadores da produção industrial, principalmente inglesa.

A partir do início do século XXI o número de reuniões científicas aumentou significativamente no Brasil. Podemos citar o I Encontro Latino-Americano / V Seminário Nacional de Preservação e Revitalização Ferroviária, realizado em 2001 na Universidade Metodista de Piracicaba - UNIMEP, no estado de São Paulo, o "VII Encontro de Teoria e História da Arquitetura do Rio Grande do Sul: Arquitetura Industrial", realizado em 2003 pela Faculdade de Engenharia e Arquitetura da Universidade de Passo Fundo - FEAR/UPF, no Rio Grande do Sul, entre outros. Além disso o TICCIH-Brasil vem atuando no país na realização de encontros e discussões sobre o assunto, tendo organizado, no mesmo ano de sua fundação, o I Encontro em Patrimônio Industrial, realizado na Universidade Estadual de Campinas - UNICAMP, no estado de São Paulo, e, em 2009 o II Encontro em Patrimônio Industrial no Centro Universitário Belas Artes de São Paulo - FEBASP.

Apesar de todas estas iniciativas, a proteção do patrimônio industrial ainda é muito aquém da desejada. No estado de São Paulo, onde vemos presença e atuação do poder público na proteção do

\footnotetext{
40 Devemos aqui abrir parênteses e observar que a tradição britânica em relação ao patrimônio é de atuar via sociedade civil organizada. Como coloca Jokilehto (1999, p. 156), “A proteção de edifícios históricos na Inglaterra tem sido baseada nos esforços de indivíduos. Mesmo no século XX, esforços significativos para manter e reparar as grandes catedrais do país foram baseados substancialmente em financiamentos privados. Na crítica das restaurações francesas a culpa foi muitas vezes dada à centralidade do sistema". (Do original: "The protection of historic buildings in England has long been based on the efforts of individuals. Even in the twentieth century, significant efforts to maintain and repair the great cathedrals of the country have been based substantially on private funding. In the criticism of French restorations the blame was often given to the centrality of the system"). Desta forma, temos um Estado presente, porém de modo mais limitado, com forte atuação de sociedades voluntárias, como pudemos observar na primeira parte desta dissertação. Já na França, como observado por Jokilehto, o sistema "leva a culpa", ou seja, o Estado é responsável pela preservação, podendo haver participação da população, porém não de forma tão sistemática quanto na Inglaterra. No Brasil temos uma estrutura similar à francesa, com a preservação mais associada às estruturas estatais.
}

41 Carta de Campinas - Declaração do GEHT em defesa das construções e instalações utilitárias, 29 de janeiro de 1998. Disponível em: http://cordiolli.files.wordpress.com/2011/06/declara-geht-carta-de-campinas.pdf. Acesso em 06/02/2012. 
patrimônio cultural já consolidada, com mais de 300 edifícios tombados pelo Conselho de Defesa do Patrimônio Histórico, Arqueológico, Artístico e Turístico de São Paulo - CONDEPHAAT42, e de 58 edifícios pelo IPHAN, apenas uma pequena parcela desses tombamentos é relativa ao patrimônio industrial (Rodrigues, 2010). Mesmo assim, São Paulo é um dos estados brasileiros que apresenta maior preocupação em relação aos remanescentes da industrialização.

\subsection{0 patrimônio industrial na Bahia}

As primeiras iniciativas em relação à preservação de bens do processo de industrialização na Bahia ocorreram na década de 1940, com o tombamento dos dois engenhos anteriormente citados (Matoim e Freguesia) pelo órgão nacional de preservação (IPHAN). Porém, como já foi dito, estes tombamentos ainda não foram motivados pelo reconhecimento do patrimônio industrial e sua necessidade de preservação, mas sim como patrimônio arquitetônico colonial.

Segundo o professor da FAUFBA Nivaldo Andrade Junior "o marco mais significativo de uma preocupação com a preservação dos valores culturais estritamente ligados ao passado industrial de um bem tombado é a polêmica que envolveu a destruição de parte do Conjunto do Unhão em Salvador e a posterior instalação, no local, dos Museus de Arte Moderna e de Arte Popular da Bahia." (Andrade Junior, 2011, p. 11). De fato, houve uma grande repercussão em prol da manutenção do edifício, que estava ameaçado de ser demolido em 1959, para a construção de uma avenida à beira-mar - a "Avenida de Contorno" - que passaria por dentro do Conjunto do Unhão. Graças ao professor da FAUFBA Diógenes Rebouças (também engenheiro agrônomo e arquiteto) que fez uma proposta alternativa, onde a nova avenida desvia do conjunto, este acabou sendo preservado. 0 conjunto já era tombado pelo IPHAN desde 1943 (tombamento citado anterior-mente) e sua preservação certamente se manifesta pelo seu valor histórico colonial, e não pela importância dada à história da industrialização no país. Após o incidente o conjunto foi desapropriado pelo Governo do Estado da Bahia e, em 1962, a arquiteta Lina Bo Bardi iniciou o projeto de restauração do conjunto e sua adaptação para receber o Museu de Arte Moderna e o Museu de Arte Popular. Sobre o edifício, a arquiteta comenta:

O Conjunto do Unhão é importante por representar um dos primeiros exemplos (se não o $\left.1^{\circ}\right)$ de Arqueologia Industrial, isto é: uma restauração não somente limitada à recuperação até o século XVIII, mas uma recuperação dedicada também à documentação do 'trabalho' e de um território, neste caso, uma 'fábrica' do começo do século XIX (Bardi apud Andrade Junior, 2011, p. 12).

Outra situação onde houve uma grande manifestação popular e, desta vez, com o foco realmente na memória da industrialização foi a demolição da Fábrica de Papel da Bahia - FAPELBA, localizada no bairro do Rio Vermelho, Salvador-BA. 0 edifício foi construído para abrigar uma fábrica de cervejas em 1920 e, com o passar do tempo, abrigou fábricas de estopa, gelo e, por fim, papel. Devido à poluição que esta causava ao Rio Camurujipe, a FAPELBA transferiu-se para outro sítio, no início da década de 1980, abandonando o antigo edifício. Em 1984 anunciou-se a demolição do edifício, devido à sua localização privilegiada, para dar lugar a um posto de gasolina. Houve grande mobilização da população, em especial dos moradores do bairro, intelectuais e artistas, como Fernando Gabeira, Jorge Amado, Caetano Veloso e Gilberto Gil. Criaram o Movimento de Defesa da Fábrica do Rio Vermelho com o slogan "assuma a fábrica - vamos preservar um pedaço da nossa história", pedindo a desapropriação do edifício pela prefeitura e sua transformação em centro cultural, nos moldes do SESC Pompéia de São Paulo. Infelizmente o protesto não conseguiu impedir a demolição da fábrica, que teve início em outubro de 1985. Dela restou apenas uma chaminé (Figura 1), que dá nome ao posto de gasolina (Andrade Junior, 2011).

Diferentemente do que ocorreu na Inglaterra, a perda polêmica de um exemplar representativo da arquitetura industrial não despertou na população o ímpeto preservacionista em relação a estes bens. As perdas de exemplares da arquitetura industrial não pararam por aí e muitos outros edifícios que não estavam tão em foco, e nem em local tão privilegiado, foram demolidos sem ao menos serem notados.

\footnotetext{
42 Segundo Rodrigo Modesto Nascimento (2010) dos 353 bens culturais tombados pelo CONDEPHAAT, no estado de São Paulo, de 1969 a 2010, apenas 27 bens, salvo engano, são de natureza industrial, isto é, menos de $10 \%$ do total, com destaque às estações ferroviárias.
} 


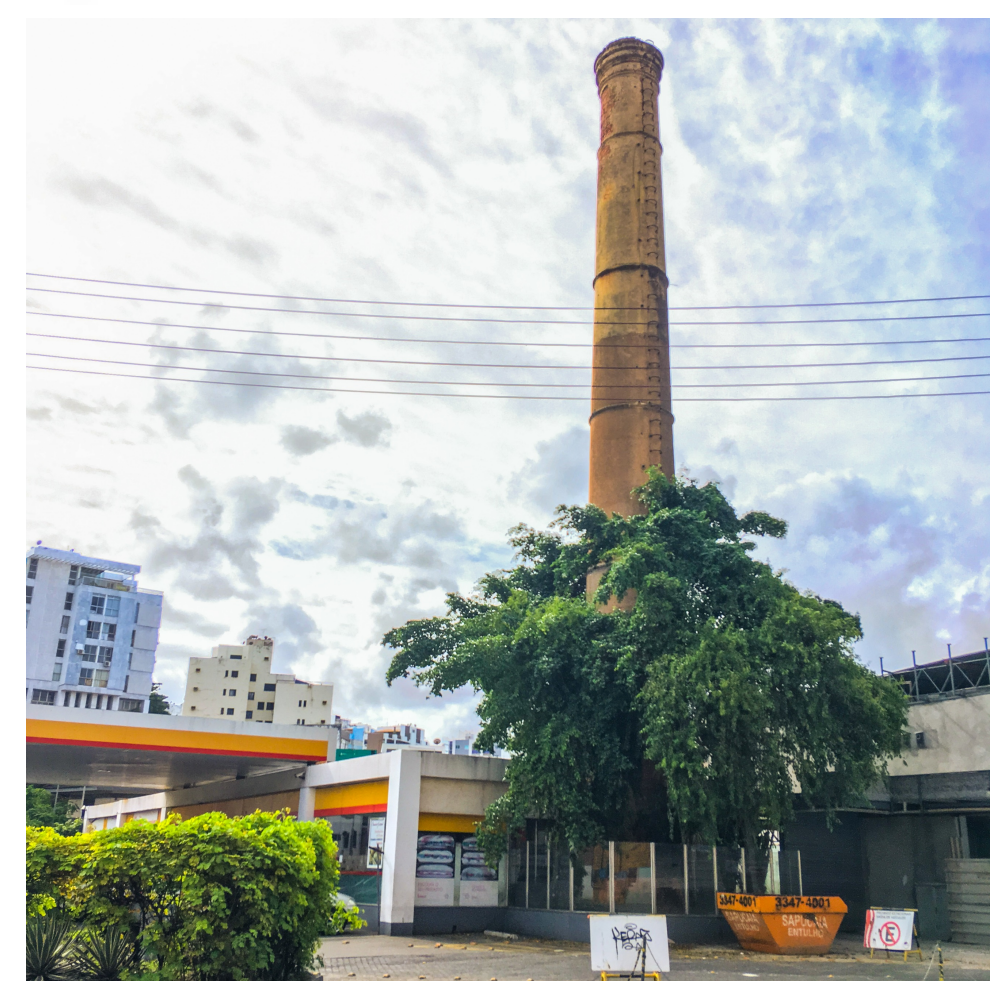

Figura 1. Chaminé remanescente da FAPELBA. Fonte: Acervo da autora, 2018.

Na década de 1970 uma iniciativa realmente chamou a atenção no meio da preservação de monumentos em geral com a realização do Inventário de Proteção do Acervo Cultural da Bahia, chegando este, inclusive, a abarcar o patrimônio industrial. Esta "experiência pioneira de inventário do patrimônio edificado, levada a cabo pelo Governo Estadual durante mais de vinte anos, é representativa do processo progressivo de valorização do patrimônio industrial" (Andrade Junior, 2011, p. 13). 0 Inventário foi realizado pela Secretaria da Indústria e Comércio do Estado da Bahia e coordenado pelo Prof. Paulo Ormindo de Azevedo, tendo o seu início em 1973 e fim na década de 2000, abrangendo quase todo o território baiano em sete volumes.

Nesse inventário inicialmente, no primeiro volume, de 1975, o patrimônio industrial foi praticamente desconsiderado, sendo incluído progressivamente a partir do segundo volume, de 1978, assim como ocorreu com outras categorias que eram consideradas menos importantes, como, por exemplo, a arquitetura eclética. Deve-se observar que o Inventário, em seu início, seguia a mesma linha do IPHAN, com um foco maior no patrimônio colonial, documentando, assim, o que poderiam ser considerados os remanescentes industriais da colônia.

Desta forma, no primeiro volume, dedicado aos Monumentos do Município de Salvador, já existe a setorização "Arquitetura Industrial ou Agrícola", que conta com a documentação da Quinta e Solar do Unhão, edifício tombado pelo IPHAN, citado anteriormente. Já nos dois volumes seguintes, ambos de 1978, dedicados aos Monumentos e Sítios do Recôncavo, encontramos alguns exemplares da arquitetura industrial, sendo documentados o Sobrado da Fábrica Suerdieck (sobrado de meados do século XIX adaptado ao uso fabril) e a Antiga Fábrica Dannemann, ambos em Maragogipe, a Estação Ferroviária de Nazaré, e a Imperial Ponte D. Pedro II (Figura 2), ponte metálica do final do século XIX que liga a cidade de Cachoeira à cidade de São Félix. Em relação à arquitetura da agroindústria açucareira do período colonial foram documentadas as fábricas dos engenhos: Cajaíba, em São Francisco do Conde; Pimentel, em São Sebastião do Passé; Vitória, em Cachoeira; Palmeira, em Santo Antônio de Jesus; além do Antigo Engenho São Pedro (engenho de açúcar com casa-grande e fábrica acopladas), em Nazaré. Dos engenhos tombados pelo IPHAN (Matoim e Freguesia) foram documentadas as Casas Grandes e a Fábrica do Engenho Freguesia. Diversas outras Casas Grandes e Igrejas de Engenhos foram documentadas.

No quarto volume, relativo aos Monumentos e Sítios da Serra Geral e Chapada Diamantina, de 1980, foi documentado apenas o Engenho Cachoeira de Utinga, na cidade de Utinga, sendo registrado o 
edifício do engenho de açúcar, onde se conservavam, no momento da realização do inventário, roda d'água de madeira, moenda de ferro de eixo horizontal e remanescentes de antigos carros de boi.

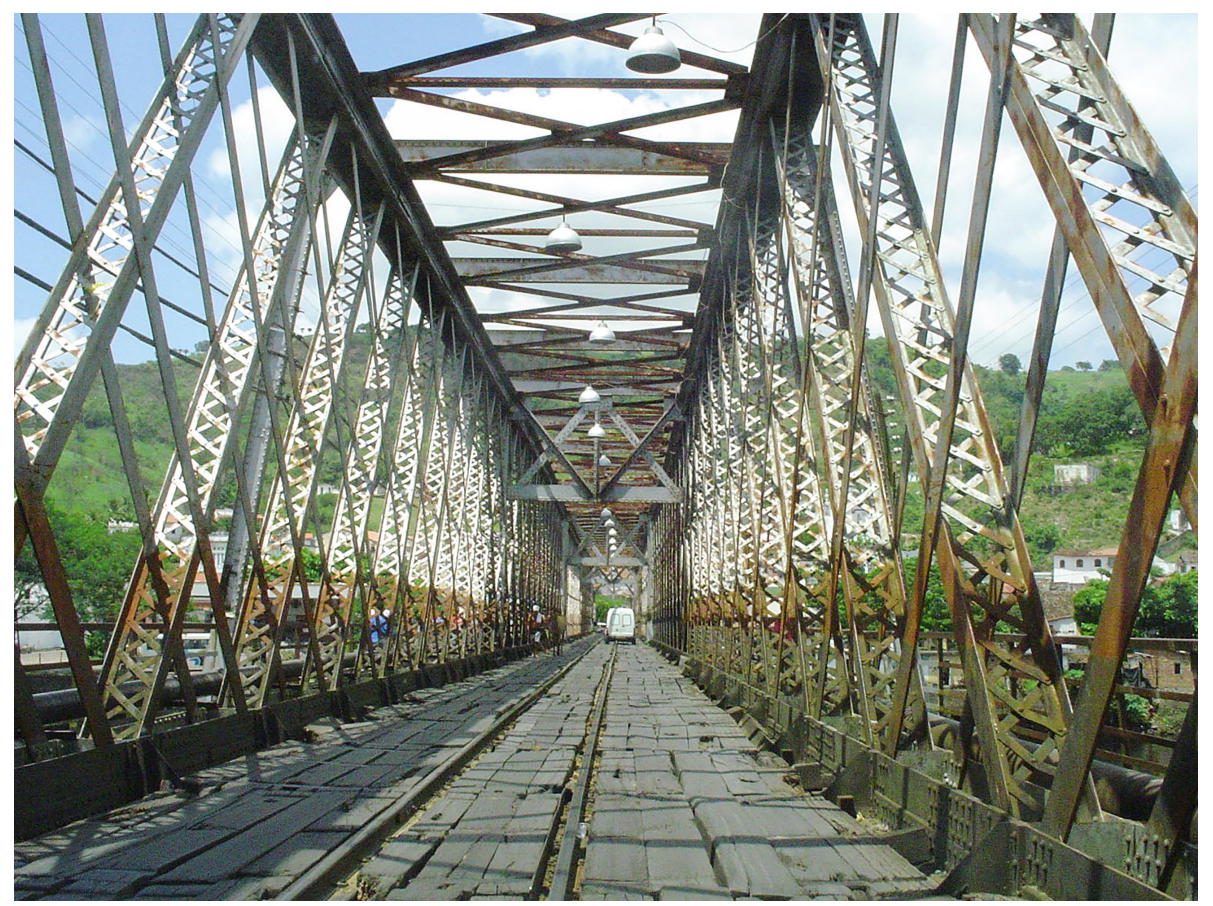

Figura 2. Imperial Ponte D. Pedro II, que liga Cachoeira a São Félix. Fonte: Acervo da autora, 2005.

Já o quinto volume, dedicado aos Monumentos e Sítios do Litoral Sul, de 1986, apresenta documentada uma maior quantidade de bens relativos à arquitetura industrial. Valença, que foi um polo da indústria têxtil, teve duas das suas fábricas documentadas: a Fábrica Todos os Santos, ruínas de interesse histórico da terceira fábrica de tecidos e primeira grande indústria fundada na Bahia, cujo projeto e instalação foram confiados ao eng. norte-americano João Monteiro Carson; e a Fábrica N. S. do Amparo, complexo industrial dedicado à fabricação de tecidos que desde 1887 faz parte da Fábrica de Tecidos da Cia. Valença Industrial43, sendo, hoje a mais antiga fábrica de tecidos em atividade no país, sendo também documentada a sua Vila Operária (que foi construída em diversas etapas entre os anos de 1920 e 1937). Neste mesmo volume também foram documentadas a Estação Ferroviária de Helvécia (da antiga linha férrea Bahia-Minas), o Engenho de Dendê e Piaçava, edificações para fabricação de óleo de dendê e beneficiamento de piaçava, em Camamu, e duas Casas de Farinha, em Alcobaça, sendo que um dos edifícios ainda mantém íntegro o antigo maquinário para o processamento da mandioca e beneficiamento de café e o outro ainda produz farinha de mandioca com maquinário primitivo.

No sexto, referente aos Monumentos e Sítios das Mesorregiões Nordeste, Vale Sanfranciscano e Extremo Oeste Baianos, de 1999, vemos uma atenção especial dada ao patrimônio ferroviário, sendo que a linha da Bahia and San Francisco Railway Company passa por esta região, havendo um reconhecimento desta arquitetura. Foram documentados em Alagoinhas a Estação Férrea S. Francisco e o Chalé da Rede Ferroviária Federal S.A. - RFFSA, que servia como residência do agente da Estação São Francisco; em Jaguarari, a Estação de Barrinha; em Senhor do Bonfim, a Estação Férrea Senhor do Bonfim; e, em Juazeiro, a Estação Velha de Juazeiro, junto com as Casas do Agente e do Engenheiro da RFFSA. Ainda foi documentado um exemplar da agroindústria, o Engenho da Fazenda Caritá, na cidade de mesmo nome.

O sétimo e último volume, do ano de 2002, referente aos Monumentos da Região Pastoril do Estado da Bahia apresenta uma maior presença da arquitetura menor e popular, de valor principalmente ambiental. A Estação Ferroviária de João Amaro, distrito de Iaçu, foi documentada.

\footnotetext{
43 Deve-se observar que estas fábricas fazem parte de um mesmo conjunto, já que em 1861 a Fábrica Todos os Santos se fundiu à N. S. do Amparo.
} 
É interessante observar o processo de reconhecimento da arquitetura ferroviária. No primeiro volume do Inventário a Estação da Calçada, em Salvador, uma das estações mais importantes da Bahia and San Francisco Railway Company, não foi considerada; já no sexto volume muitas outras estações foram incluídas, algumas muito mais modestas e com menos importância e representatividade.

No meio acadêmico podemos notar um interesse maior pelo tema do patrimônio industrial. Deve ser citada novamente a dissertação de mestrado do professor José Luis Pamponet Sampaio, apresentada no ano de 1975 ao Mestrado em Ciências Humanas da Universidade Federal da Bahia, sobre a Companhia Empório Industrial do Norte. 0 próprio Pamponet foi possuidor de um vasto arquivo relativo às indústrias, que hoje se concentra no Centro de Documentação e Pesquisa (CEDOC) da Universidade Estadual de Feira de Santana (UEFS). Apenas dez anos após esta dissertação outro estudo acadêmico sobre o tema foi realizado pela professora da FAUFBA Esterzilda Berenstein de Azevedo, cujo título é "Arquitetura do Açúcar", apresentado ao Mestrado em Ciências Sociais da UFBA. Em 1996 a mesma defendeu sua tese de doutorado na FAU/USP, ainda trabalhando com o tema dos engenhos, cujo título é "A construção de engenhos na Bahia oitocentista". Em 1991, o também professor da FAUFBA Luiz Antonio Fernandes Cardoso apresentou a dissertação sobre as vilas operárias, de título "Entre Vilas e Avenidas: Habitação Proletária em Salvador na Primeira República" no Mestrado em Arquitetura e Urbanismo da FAUFBA, na área de Conservação e Restauro, reafirmando o interesse, ao menos no meio acadêmico, pelo legado deixado pela indústria na Bahia. Porém, como pode ser observado, este interesse ainda é incipiente, especialmente quando pensamos na amplitude do tema.

O século XXI chegou com nova força ao estudo do patrimônio industrial na Bahia, contando com uma nova geração interessada em desenvolver o assunto. Podemos destacar a dissertação de mestrado de Ceila Rosana Carneiro Cardoso realizada na Escola de Engenharia de São Carlos da USP (Programa de Pós-graduação em Tecnologia do Ambiente Construído - Mestrado em Teoria e História da Arquitetura) em 2004 com o título "Arquitetura e Indústria: A Península de Itapagipe como sítio industrial da Salvador Moderna 1891 - 1947", o trabalho de Nara de Souza Gomes apresentado em 2007 para a conclusão do curso de graduação em História com Habilitação em Patrimônio Cultural pela Universidade Católica do Salvador, de título "Inventário do Patrimônio Industrial Têxtil na Península de Itapagipe - Salvador-BA" e os artigos "Do ouro branco ao ouro negro: as políticas públicas de preservação do patrimônio industrial na Bahia" de 2011 do professor Nivaldo Vieira de Andrade Júnior, "A arquitetura fabril na Bahia: um patrimônio desconhecido" e "A preservação do patrimônio arquitetônico industrial na Bahia", ambos de 2009, "As manufaturas de fumo do Recôncavo Baiano" de 2011, e "Manufaturas de fumo do Recôncavo Baiano: vestígios de patrimônio industrial", de 2014, sendo os quatro últimos escritos pela professora da FAUFBA Luciana Guerra Santos Mota e a dissertação de mestrado de Maria Elena Castore, realizada no PPGAU - UFBA, intitulada "A fábrica e o bairro: Um estudo sobre a paisagem industrial no bairro da Plataforma em Salvador", de 2013. Além disso, diversos trabalhos vêm sendo desenvolvidos no Mestrado Profissional (MP-CECRE) da UFBA com projetos de intervenção em edifícios industriais.

Assim como no resto do país, na Bahia não se desenvolveu uma política específica para a preservação do Patrimônio Industrial. A professora Luciana Guerra Mota coloca que "A Bahia, por exemplo, apesar de apresentar uma significativa importância histórica na instalação da indústria moderna no país ocorrida durante o século XIX, poucos são os monumentos industriais reconhecidos como patrimônio cultural." (Mota, 2009, p. 02). Ainda podemos encontrar vestígios deste patrimônio industrial espalhados por todo território baiano, representados por indústrias, maquinários, estações e ferrovias, pontes, túneis, etc. O IPHAN, órgão responsável pelo tombamento dos engenhos anteriormente citados na Bahia, não realizou tombamentos de exemplares do patrimônio da industrialização mais recente no estado, de finais do século XIX e do século XX.

A partir de 2002 o Instituto do Patrimônio Artístico Cultural da Bahia (IPAC-BA) 44 iniciou o tombamento de edifícios relativos ao processo de industrialização. Naquele mesmo ano foram tombados

\footnotetext{
44 O IPAC é um dos primeiros órgãos do Brasil voltados para o patrimônio cultural, sendo fundado em 13 de setembro de 1967. Atua em todo o estado da Bahia, realizando a proteção dos exemplares mais significativos para o estado e incentivando a atuação de órgãos municipais de proteção do patrimônio histórico, artístico e cultural. No site da instituição (http://www.ipac.ba.gov.br/) pode ser encontrada a lista de bens tombados pela mesma.
} 
o Engenho de Baixo45, no município de Aratuípe; a Estação Ferroviária São Francisco46, cujo processo de tombamento havia sido iniciado em 1991, em Alagoinhas; a Ponte D. Pedro II ${ }^{47}$, que liga Cachoeira a São Félix; a Antiga Fábrica São Brás48, cujo tombamento havia sido solicitado cinco anos antes pela Associação de Moradores de Plataforma - AMPLA, em Salvador; e a Antiga Fábrica Fratelli Vita ${ }^{49}$, na Península de Itapagipe, também em Salvador. No ano de 2004 foi tombada a Fábrica do Engenho Cajaíba50, junto com o sobrado do engenho, em Cajaíba. Após este tombamento apenas em 2011 foi realizado outro relativo ao patrimônio industrial, com o debatido tombamento da Usina Cinco Rios ${ }^{51}$, em São Sebastião do Passé. A Estação Ferroviária Alexandre Bittencourt52, em Nazaré, encontra-se em tombamento provisório desde 02/08/1989. Não foram tombados outros edifícios relativos ao processo de industrialização na Bahia até a presente data.

Desde os tombamentos desses edifícios pode ser observada a continuação do processo de degradação, pois o tombamento não é uma medida que compele os proprietários a realizar intervenções de manutenção, conservação ou restauro. Sem estas intervenções, que ajudam a conter a ação do tempo, o edifício passa pelo seu processo natural de degradação, chegando, muitas vezes, a níveis críticos de depreciação física, fazendo com que uma intervenção severa seja, muitas vezes, necessária. Desta forma, pode-se observar que existe uma lacuna entre o tombamento e a preservação.

O mesmo ocorre com os edifícios que não tiveram o seu valor reconhecido por tombamento ou qualquer outro tipo de proteção. Também estão suscetíveis às ações do tempo e do vandalismo, porém, sem uma proteção legal que ao menos impeça que medidas drásticas sejam tomadas sem o conhecimento dos órgãos de preservação, estão passíveis de qualquer tipo de intervenção danosa ou demolição.

Na cidade de Salvador, o órgão responsável pelos tombamentos municipais é a Fundação Gregório de Mattos (FGM), que teve sua lei de tombamento aprovada em 2013 (Projeto de Lei no 622/2013). A FGM é um órgão vinculado à Secretaria Municipal de Cultura e Turismo - SECULT, que tem como finalidade formular e executar a política cultural do Município do Salvador. A Lei no 8550/2014 instrui normas de proteção e estímulo à preservação do patrimônio cultural do município de Salvador, normatizando os processos de tombamento de bens materiais e imateriais e indica as instâncias e etapas de deliberação para o tombamento. Ainda não existem tombamentos referentes aos bens imóveis e, consequentemente, ao patrimônio industrial da cidade de Salvador.

É importante ressaltar que o Patrimônio Industrial é tão relevante quanto qualquer outro Patrimônio Cultural, e deve ser visto como tal, e as ações sobre ele devem ser coerentes e no sentido de sua preservação. Um ponto positivo para a possível salvaguarda deste patrimônio é que ainda podemos encontrar muitos remanescentes no estado da Bahia, fator muito favorável para a seleção e preservação pelo menos dos exemplares mais significativos.

45 Processo: 024/02, Notificação / Decreto: 8.357/05.11.2002. Fonte: patrimonio.ipac.ba.gov.br/ Acesso em 30/06/2018.

46 Processo: 002/91, Notificação / Decreto: 8.357/05.11.2002. Fonte: patrimonio.ipac.ba.gov.br/ Acesso em $30 / 06 / 2018$.

47 Processo: 025/02, Notificação / Decreto: 8.357/05.11.2002. Fonte: patrimonio.ipac.ba.gov.br/ Acesso em $30 / 06 / 2018$.

48 Processo: 003/97, Notificação / Decreto: 8.357/05.11.2002. Fonte: patrimonio.ipac.ba.gov.br/ Acesso em $30 / 06 / 2018$.

49 Processo: 002/00, Notificação / Decreto: 8.357/05.11.2002. Fonte: patrimonio.ipac.ba.gov.br/ Acesso em 30/06/2018.

50 Processo: 009/95 e 010/95, Notificação / Decreto: 9.214/05.11.2004. Fonte: patrimonio.ipac.ba.gov.br/ Acesso em $30 / 06 / 2018$.

51 Processo: 0607040023846, Notificação / Decreto: 13.152/09.08.2011. Fonte: patrimonio.ipac.ba.gov.br/ Acesso em $30 / 06 / 2018$.

52 Processo: 005/88, Notificação / Decreto: N. 02/08/89. Fonte: Fonte: patrimonio.ipac.ba.gov.br/ Acesso em $30 / 06 / 2018$. 


\section{0 Patrimônio Industrial da Península de Itapagipe e sua Preservação}

A Península de Itapagipe, localizada na cidade de Salvador, abrigou grande parte das indústrias implantadas na Bahia desde o início da industrialização no Brasil até a criação de novos centros industriais na segunda metade do século $\mathrm{XX}$, quando muitas empresas começaram a deixar a região, transferindo-se principalmente para o novo polo industrial, o Centro Industrial de Aratu - CIA. As indústrias trouxeram consigo programas que vão além do uso fabril, como galpões para armazenamento, vilas operárias e edifícios destinados ao funcionamento de meios de transporte.

Essa região apresenta ocupação desde antes da implantação da cidade pelos portugueses, com a presença de aldeamentos indígenas. Após a fundação da cidade abrigou, inicialmente, olarias, currais, estaleiros, engenhos e alambiques. No século XIX, antes de configurar-se como região industrial, era considerada área salubre, propícia para a instalação de equipamentos para tratamentos de enfermidades e construção de casas para veraneio.

Com o objetivo de entender a industrialização na península e mapear os edifícios utilizados pelas empresas relacionadas ao processo de industrialização foi trabalhada numerosa documentação primária, procedente de arquivos, como projetos, fotografias e documentos, e livros antigos, destacando-se os relatórios sobre a indústria. A partir dos levantamentos de campo pôde-se conhecer o universo dos remanescentes da arquitetura industrial da Península de Itapagipe 53, considerando-se o período do início da industrialização ao declínio da indústria na península (meados do século XX). No período entre o início do século XIX, quando foram implantadas as primeiras indústrias na Península de Itapagipe, até o ano de 1955 foram encontradas 111 empresas relacionadas à atividade industrial54. Destas, apenas cinquenta e seis puderam ser mapeadas durante a pesquisa documental (Figura 3), em base cartográfica do ano de 1956.
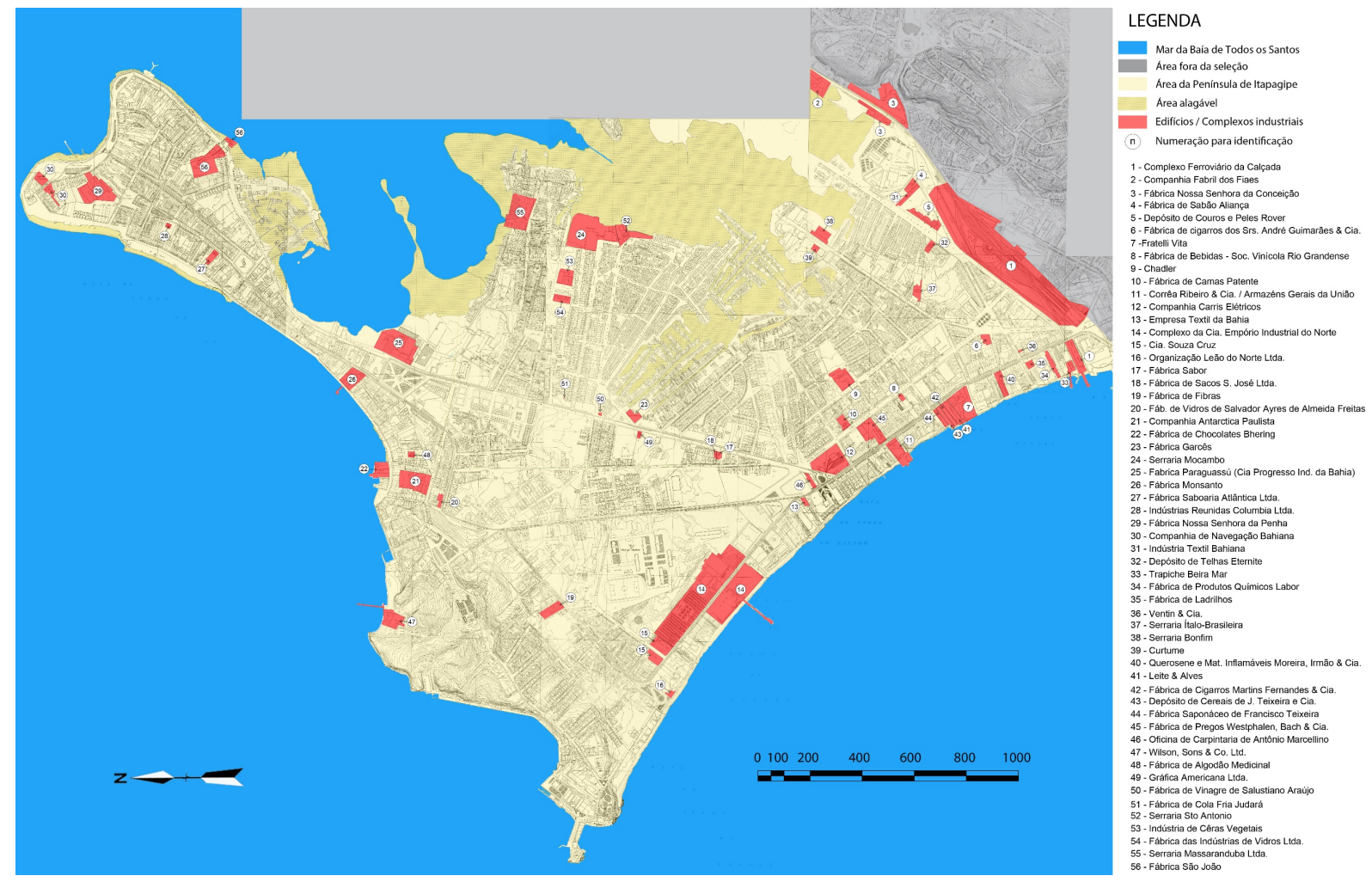

Figura 3. Mapa da Península de Itapagipe com a localização dos edifícios relativos ao processo de industrialização. Fonte: Atlas Parcial da Cidade do Salvador, 1956, editado pela autora.

53 Estes estudos foram desenvolvidos durante o mestrado em Conservação e Restauro na Faculdade de Arquitetura e Urbanismo da Universidade Federal da Bahia - Brasil.

54 Dados encontrados durante as pesquisas em livros, projetos do Arquivo Histórico Municipal de Salvador (AHMS), livros do Imposto sobre a Propriedade Predial Urbana (IPTU) do AHMS, registros de marca do Arquivo Público do Estado da Bahia (APEB) e Atlas de 1956. Para ter acesso a estes dados, ver Luther, 2012. 
A implantação das indústrias na península foi um fator que alterou bastante o seu caráter e sua composição física, já que trouxe consigo questões de salubridade, de adensamento, devido à grande quantidade de habitações construídas para abrigar os operários das fábricas, e de composição do espaço construído.

Em meados do século XX, muitas empresas começaram a deixar a área, movendo-se, principalmente, para o novo centro industrial, o Centro Industrial de Aratu - CIA, como já foi destacado. A partir deste momento e no período que se seguiu, diversos exemplares da arquitetura industrial da cidade de Salvador foram abandonados e largados à própria sorte. 0 difícil acesso dos veículos automotores à região da Península de Itapagipe "assumiu um papel de extrema importância para a preservação de algumas características físicas da área, do seu tecido urbano em frente à especulação imobiliária mais recente e a tendência de revitalização de bairros antigos para que tenham novos usos" (Cardoso, 2004, p. 151).

Atualmente, o patrimônio industrial da península sofre grandes perdas devido ao abandono de suas grandes estruturas. Muitas edificações do período industrial da Península de Itapagipe ainda permanecem na região, apesar das constantes perdas, como a Fábrica de Sabão Aliança, demolida entre 2010 e 2012, e da Estação de Roma da Companhia Carris Elétricos, demolida entre 2014 e 2015. Além das perdas, observam-se de descaracterizações constantes. Durante o período entre 2010 e $2012^{55}$ foram identificados trinta remanescentes na área ${ }^{56}$ (Figura 4). Isto quer dizer que se trata de patrimônio construído em extinção.

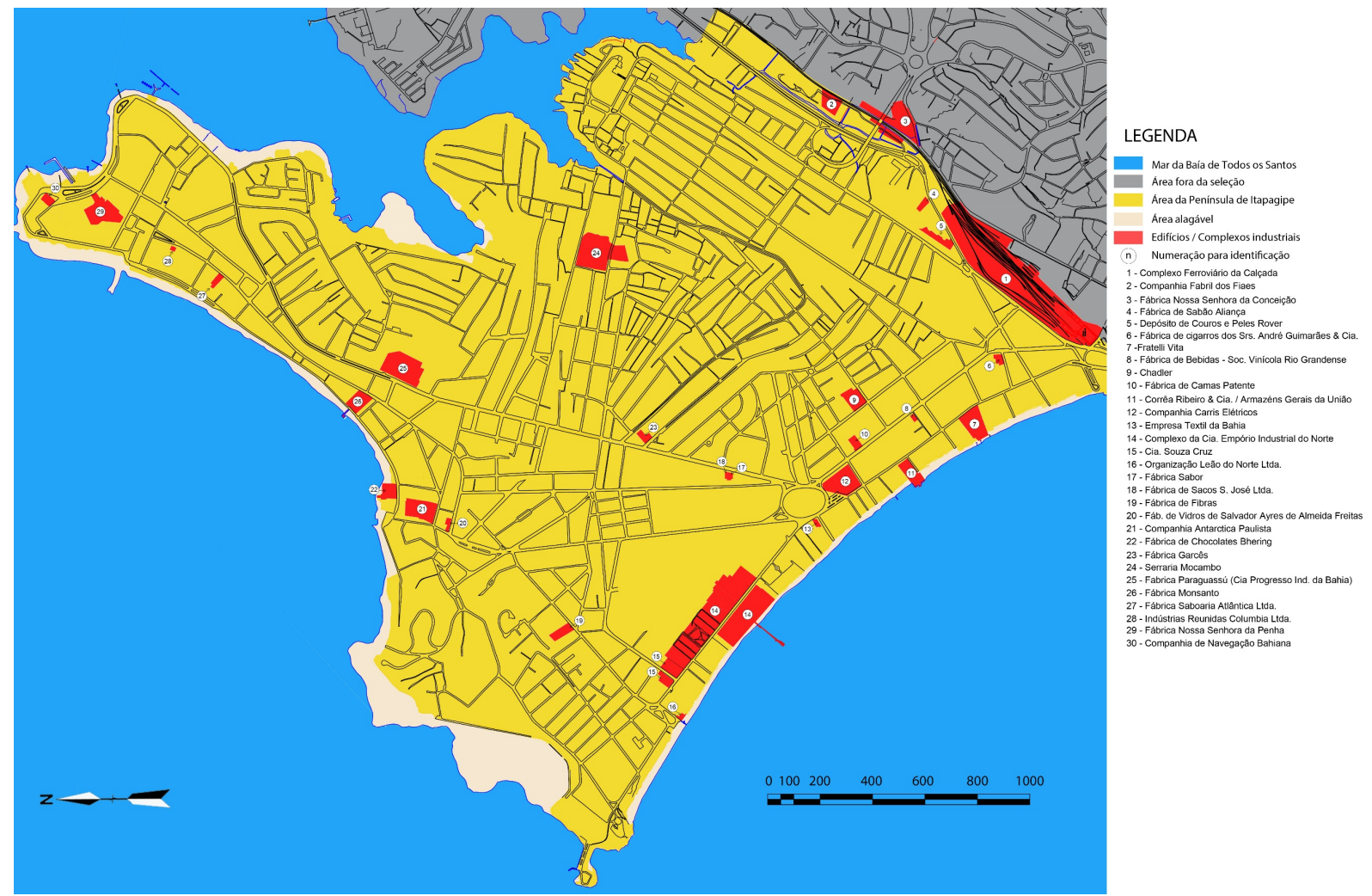

Figura 4. Mapa da Península de Itapagipe com a localização dos edifícios e conjuntos industriais remanescentes mapeados entre 2010 e 2012. Fonte: Base SICAR/RMS, digitalizada, 1991, editada pela autora.

Os edifícios identificados na Figura 4 foram inventariados, buscando-se entender a relevância de cada um deles, para realizar uma proposta em relação à preservação dos exemplares cuja relevância fosse identificada durante as pesquisas ${ }^{57}$. Foram utilizados os critérios para a seleção dos

55 Duração das pesquisas do mestrado.

56 Este número já não condiz com a realidade, uma vez que a Fábrica de Sabão Aliança e a Estação de Roma da Companhia Carris Elétricos, citadas anteriormente, foram demolidas.

57 Lembrando que qualquer proposta de preservação deve levar em consideração as premissas e valores colocados por profissionais de diversas áreas, sendo uma prática multidisciplinar, preferencialmente. 
monumentos industriais a serem protegidos estabelecidos por Buchanan (1972), autor consagrado no campo da arqueologia industrial. Poucos são os autores que abordam esta questão dos critérios para a seleção de edifícios visando a preservação e o tombamento. Buchanan é o autor mais conhecido que sistematiza esses critérios com foco no patrimônio industrial, sendo citado, inclusive, em outros escritos sobre o tema. Ele propõe seis critérios para a preservação, sendo eles:

1. Grau de excepcionalidade58 (degree of uniqueness), característico nos exemplares únicos de um tipo de artefato, no primeiro ou mais antigo, ou no último ou mais recente espécime remanescente;

2. Distinção representativa (representational distinction), ou seja, quando o exemplar apresenta uma tipologia regional, estilo de arquitetura ou design distintos, ou propriedades estruturais incomuns. Também representa os exemplares que se caracterizam como um marco ou que possuam qualidades que requeiram a preservação como um grupo;

3. Tamanho e uso (size and use), devido à ocupação do espaço. Os edifícios industriais em geral ocupam uma vasta área e a valorização desta pode ser um importante critério para a preservação, já que sofrerá maior pressão imobiliária. 0 uso (seja o original, um reuso ou uma conversão) tem uma grande importância na preservação, sendo muito mais difícil manter um edifício abandonado e sem utilidade funcional, mesmo que tenha importância histórica;

4. Possibilidade de atração do público e turística (possibility of public and tourist attraction) através da inserção de alguma atividade relacionada ao lazer, que possa, incidentalmente, gerar alguma renda para a própria manutenção do monumento, melhorando as suas perspectivas de preservação;

5. Suporte local (local support), especialmente se mostrado positivamente em termos financeiros. A possibilidade de atrair investidores (proprietários, fundos públicos ou privados) pode fazer toda a diferença entre preservação ou destruição;

6. Associações do artefato (associations of the artefact), ou seja, relações que este possa ter com um engenheiro famoso ou uma inovação técnica importante, conquistando valor em relação à sua preservação.

Estes seis critérios serviram balizar a indicação de alguns dos exemplares da arquitetura industrial da Península de Itapagipe, com foco na sua preservação. Optou-se aqui por trabalhar com os critérios da forma apresentada pelo autor, sem acrescentar novos critérios ou alterar os propostos por ele. Deve ser observado que estes critérios não são absolutos. Como foi dito anteriormente, os critérios recaem sobre as questões dos valores da sociedade vigente. Buchanan apresentou estes critérios no ano de 1972 e eles nos parecem coerentes e atuais, porém isto não os torna absolutos. Os critérios podem e devem ser questionados quando não forem adequados a determinadas situações, momentos históricos ou sociedades. Serão apresentados aqui os edifícios e os principais fatores de relevância, que justificariam a sua preservação.

0 primeiro edifício listado foi a Estação da Calçada (Figura 5), edifício inaugurado no ano de 1860 com o nome de Jequitaia - pela Bahia and San Francisco Railway Company, sendo a primeira estação desta linha, inaugurada com o primeiro trecho, que ligava a Calçada até Paripe. A Estação da Calçada e seu conjunto ferroviário, fizeram parte da Rede Ferroviária Federal S.A., fazendo parte do patrimônio da União. Foram reconhecidos diversos valores neste conjunto, podendo ser destacados os seguintes critérios que indicariam a sua preservação: grau de excepcionalidade, por ser a primeira estação a ser construída pela San Francisco Railway, além de ser a mais importante da Bahia; a distinção representativa, devido à sua arquitetura imponente, marcada pelo ecletismo e pelo seu vão interno, com cobertura abobadada, vencendo um grande vão, típica da arquitetura ferroviária; tamanho e uso, já que o conjunto ocupa uma grande área em todo o conjunto, além de apresentar o uso original, funcionando ainda como estação ferroviária; possibilidade de atração do público e turística, visto que já é bastante utilizada, podendo ter esse uso potencializado com um pouco de investimento, principalmente para a atração turística; além disso é possível receber suporte local para a sua preservação.

O segundo edifício listado, o da União Fabril dos Fiaes (Figura 6), de 1890, foi uma indústria têxtil instalada próxima à linha do trem, encontrando-se em mal estado de conservação. Um dos edifícios

$58 \mathrm{Ou}$ ainda unicidade, singularidade. 
da Fábrica dos Fiaes teve o processo de arruinamento iniciado, após a perda da cobertura. Podem ser destacados o tamanho e o uso, já que o conjunto ocupa uma grande área, de aproximadamente $25.000 \mathrm{~m}^{2}$, próxima à ferrovia, e seus edifícios apresentam usos, apesar de nem todos serem adequados aos edifícios. Existe, também, a possibilidade de atração do público ou turística, principalmente se este fosse integrado à Fábrica da Conceição, formando um parque histórico linear, estabilizando as ruinas e dando novos usos adequados aos edifícios remanescentes.

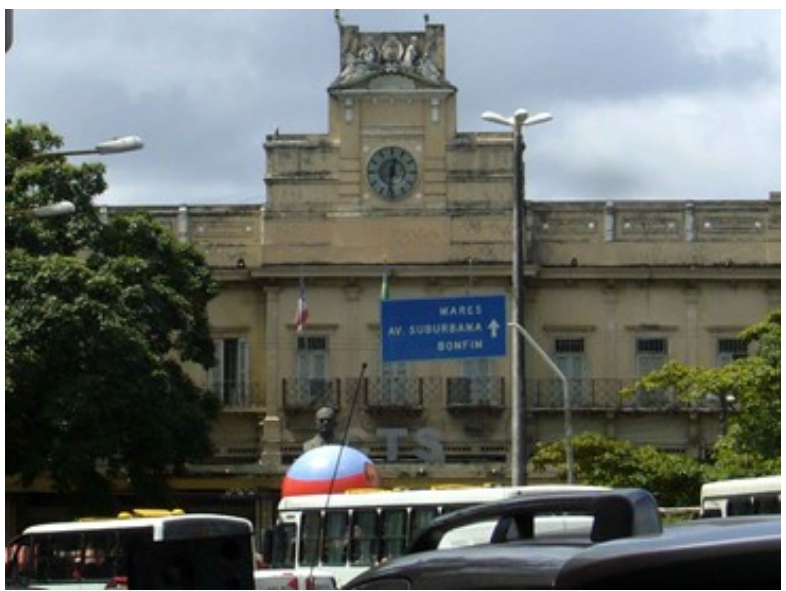

Figura 5. Estação da Calçada. Fonte: Acervo da autora, 2010.

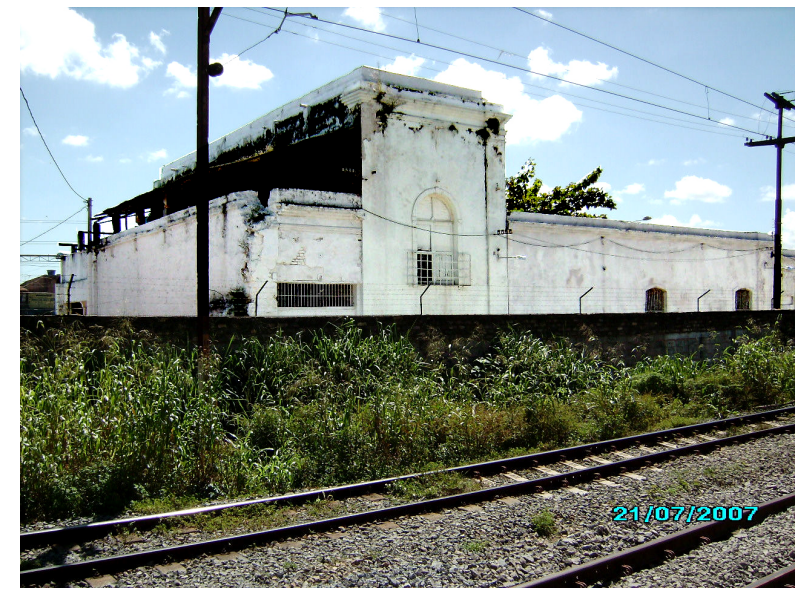

Figura 6. União Fabril dos Fiaes. Fonte: Gomes, 2007.

A Fábrica da Conceição, da Companhia Progresso e União Fabril da Bahia (Figura 7), de 1835, é a mais antiga das fábricas instaladas na península. Apresenta características semelhantes à União Fabril dos Fiaes. Ambas foram instaladas próximas à linha do trem (sendo esta anterior à implantação da ferrovia), foram indústrias têxteis e encontram-se em mal estado de conservação, havendo a fábrica da Conceição chegado um estado mais crítico de ruina. Reconhecemos nela o grau de excepcionalidade, por ser o exemplar industrial mais antigo, mesmo que parte dos edifícios remanescentes não seja do período de sua criação. Para este caso defende-se a preservação do conjunto como sítio histórico, mantendo-se as ruinas dos edifícios industriais com dignidade, aceitando usos que não venham a acelerar o processo de degradação dos remanescentes, como, por exemplo, um parque histórico. Este sítio também tem a sua importância na formação da região, por haver se instalado em terrenos do antigo Engenho da Conceição (Engenho de Itapagipe de Cima). Sua relevância vai além do município, por ser uma das primeiras indústrias a se instalar no estado da Bahia.

A Indústria de Sabões Aliança Ltda. (Figura 8) produzia sabão e óleos de babaçu, copra e ouricuri. Sabe-se, através de publicações no Diário Oficial da União, que a Indústria já existia em 1949, e que importava matéria prima dos Estados Unidos da América, como, por exemplo, Nitrato de Potássio e Soda cáustica sólida. 0 edifício foi ocupado por fábrica de vassouras, oficina mecânica e funilaria de veículos, usos que permaneciam no edifício no ano de 2007. Foi demolido entre 2010 e 2012.

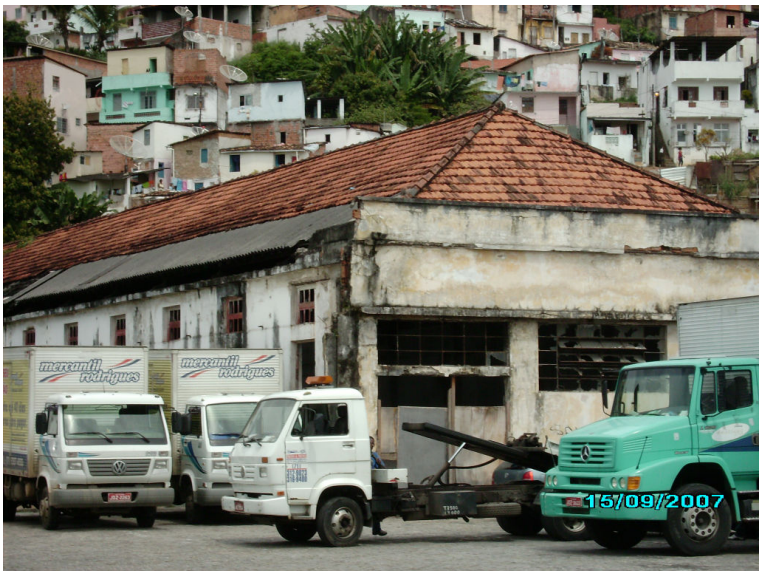

Figura 7. Fábrica da Conceição. Fonte: Gomes, 2007.

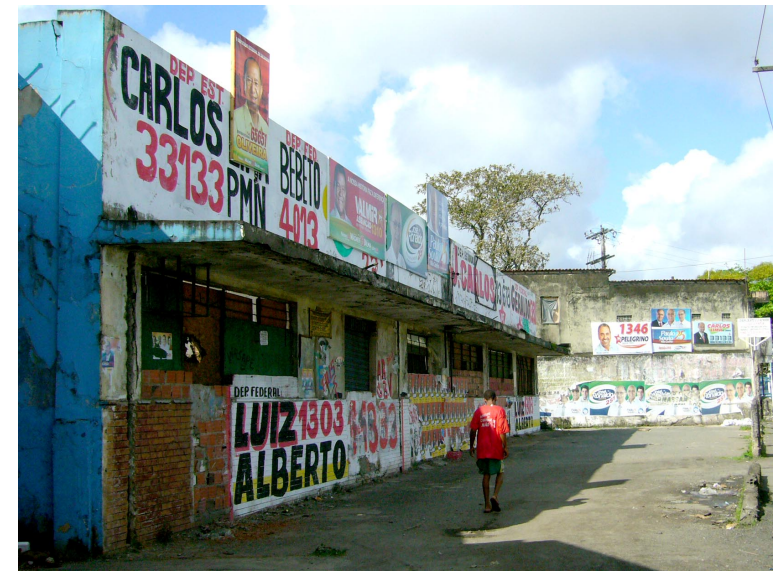

Figura 8. Indústria de Sabões Aliança Ltda. Fonte: Acervo da autora, 2010. 
O edifício da Depósito de Peles e Couros da Rover (Figura 9) é anterior ao ano de 1956, já que o levantamento do Atlas Parcial da Cidade do Salvador é do ano de 1955, porém não se pode precisar o ano da sua construção. Segundo informações dos moradores o edifício já foi ocupado pela Metalúrgica Ramos, Indaiá Transportes e Sambra. 0 edifício ocupa um terreno significativo próximo à linha ferroviária.

A Fábrica de Cigarros dos Srs. Guimarães André \& Cia. (Figura 10), cuja primeira referência é do ano de 1919, encontra-se localizado no Largo dos Mares, sendo esta uma das características que faz com que este exemplar apresente possibilidade de atração do público e turística e que consiga suporte local. 0 edifício, que ocupa um grande terreno na esquina entre o Largo e a Travessa dos Mares, inserido no meio da densa malha urbana da região, marca visualmente um dos lados do largo e da travessa.

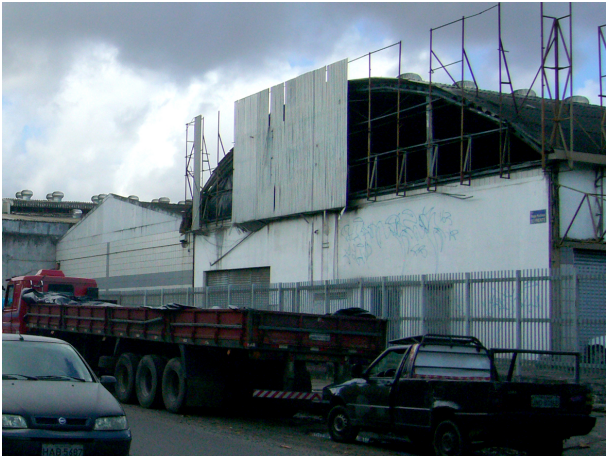

Figura 9. Depósito de Peles e Couros da Rover. Fonte: Acervo da autora, 2010.

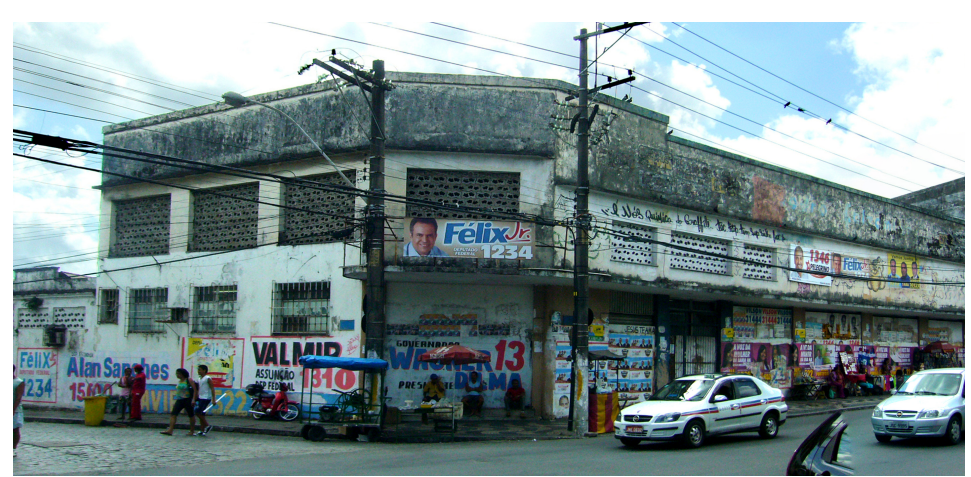

Figura 10. Fábrica de Cigarros dos Srs. Guimarães André \& Cia. Fonte: Acervo da autora, 2010.

A Fratelli Vita (Figura 11), de 1902, é o único exemplar do patrimônio industrial da península protegido. Teve seu reconhecimento, possivelmente, devido à sua distinção representativa, da arquitetura da elite de uma época, imponente, com vitrais e um belo hall de entrada. Também ocupa um grande lote, sendo selecionado pelo critério do tamanho e uso, passou, durante o período de 2010 a 2012 por obras de restauro para receber um novo uso, integrando o conjunto das Faculdades Integradas da Bahia - FIB, sendo atualmente parte do Centro Universitário Estácio da Bahia. Nas obras buscou-se resgatar a imagem do edifício principal do conjunto, refazendo-se as argamassas e substituindo peças para trazer a integralidade do edifício. Existe também a possibilidade de atração do público e turística, já que a faculdade permite o acesso aos seus edifícios, porém não tão livremente quanto um edifício público.

A Sociedade Vinícola Rio-Grandense Ltda. (Figura 12) foi fundada em 5 de junho de 1929. A Sociedade foi criada para defender os interesses dos vinicultores, e visava a compra, produção e venda do vinho. A filial de Salvador foi fundada em 1936. Não foram encontradas as informações sobre quando a Sociedade Vinícola Rio-Grandense passou a ocupar o edifício, nem quando deixou de ocupá-lo.

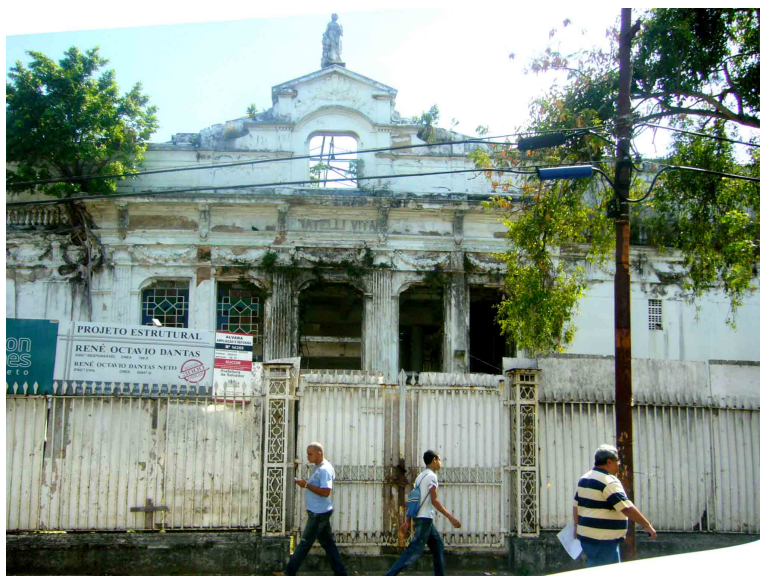

Figura 11. Fratelli Vita. Fonte: Acervo da autora, 2009.

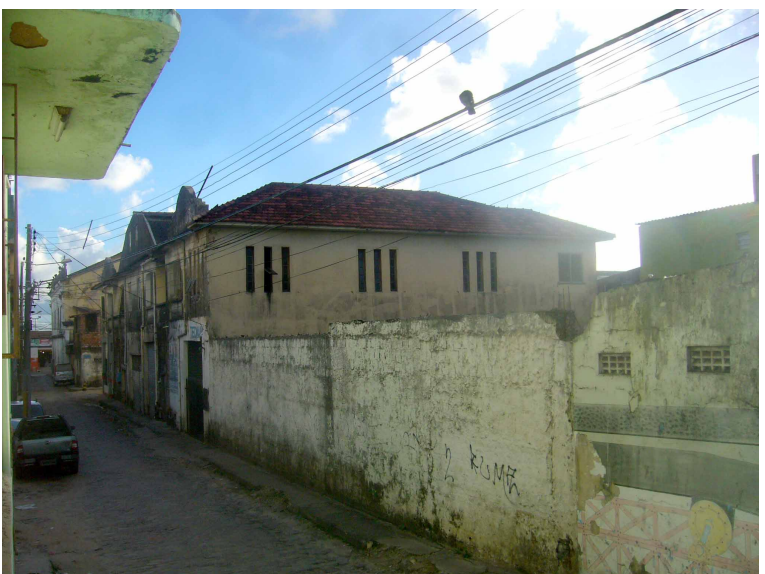

Figura 12. Fábrica de Bebidas - Sociedade Vinícola Rio Grandense. Fonte: Acervo da autora, 2012. 
A Chadler Industrial da Bahia S.A. (Figura 13) foi fundada em 1944 e ficou muito conhecida devido à polêmica causada por questões ambientais (como emissão de gases nocivos à saúde, poluição sonora, etc.) e à explosão de uma caldeira em 1962. Os moradores da região montaram uma associação para lutar pela a retirada da fábrica de chocolates Chadler. Em 1969 houve protestos da população, que chegou, inclusive, a invadir a fábrica. 0 conjunto da fábrica da Chadler é formado por diversos edifícios que ocupam metade do quarteirão. Comparando o Atlas de 1956 e a foto aérea atual, pode-se observar que apenas os dois edifícios voltados para a Rua Conselheiro Zacarias existiam.

O edifício abrigou a Fábrica de Camas Patente (Figura 14), segundo informações contidas no Atlas de 1956. 0 edifício também abrigou a Indústria de Refresco da Bahia Ltda. Em 2007 a FITFORM, empresa que trabalha com materiais para construção, já se encontrava ocupando a parte central do edifício. 0 edifício foi dividido em três blocos para abrigar diferentes usos, sendo realizadas obras para tal. Apresenta possibilidade de atração do público, devido à sua localização.

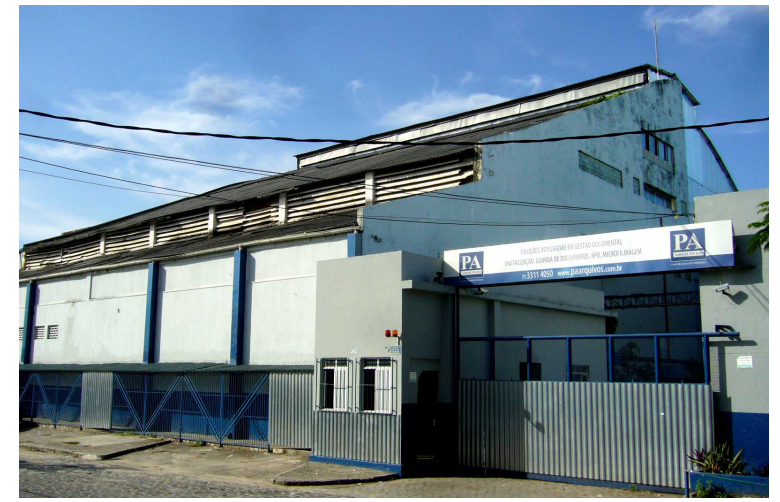

Figura 13. Chadler Industrial da Bahia S.A. Fonte: Acervo da autora, 2011.

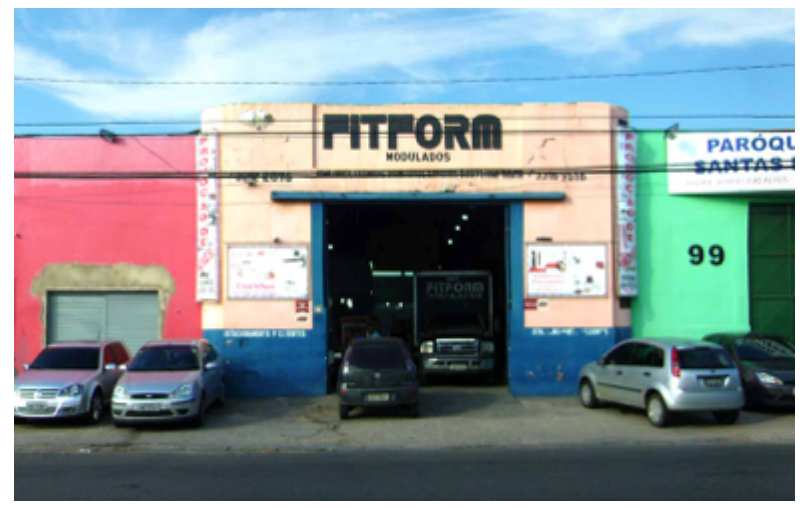

Figura 14. Fábrica de Camas Patente. Fonte: Acervo da autora, 2011.

A empresa Corrêa Ribeiro \& Cia. apresentou o projeto para construção do edifício em 1947 e em 1948 a Corrêa Ribeiro \& Cia. fundou a Armazéns Gerais e Empreendimentos União S/A, empresa de armazenagem de mercadorias, nome que consta identificando o edifício no Atlas de 1956. Provavelmente naquele mesmo ano a nova empresa passou a ocupar o edifício. Apresenta possibilidade de atração do público, devido à sua localização.

O conjunto da Companhia Carris Elétricos (Figura 16), cujo edifício principal era, possivelmente, do ano de 1897, tinha uma grande importância para a história da eletricidade no Brasil por ser uma das primeiras companhias a eletrificar as suas linhas (Salvador foi a segunda capital a ter tal serviço). Possivelmente era o último remanescente das estações de bonde da cidade de Salvador. Desta forma, foi conferido ao conjunto o grau de excepcionalidade. 0 tamanho e o uso também foram destacados, já que o conjunto ocupava um quarteirão com localização privilegiada, no Largo de Roma, e apresentava uso, apesar de não adequado. Existia a possibilidade de atração do público e turística, sendo a localização um fator muito favorável. Os trechos remanescentes da fachada até 2014, em arruinamento, ainda apresentavam beleza, porém não mais aquela beleza íntegra, não sendo este um critério determinante para a sua preservação. Como foi dito, o edifício foi demolido entre 2014 e 2015, e seria um exemplar digno de preservação.

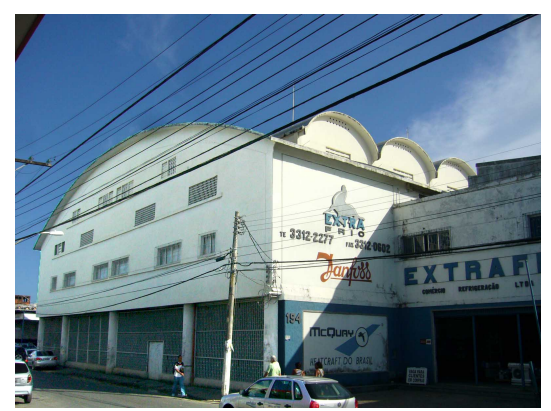

Figura 15. Indústria de Sabões Aliança Ltda. Fonte: Acervo da autora, 2011.

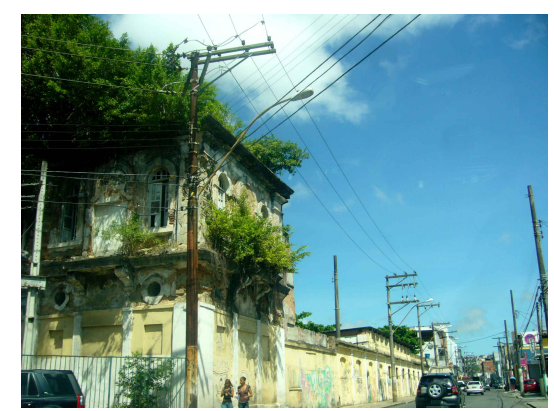

Figura 16. Companhia Carris Elétricos. Fonte: Acervo da autora, 2009. 
A única referência sobre a Empresa Têxtil da Bahia (Figura 17) é do ano de 1935, no Livro do IPTU deste ano. Apresenta possibilidade de atração do público, devido à sua localização, em frente ao Largo de Roma.

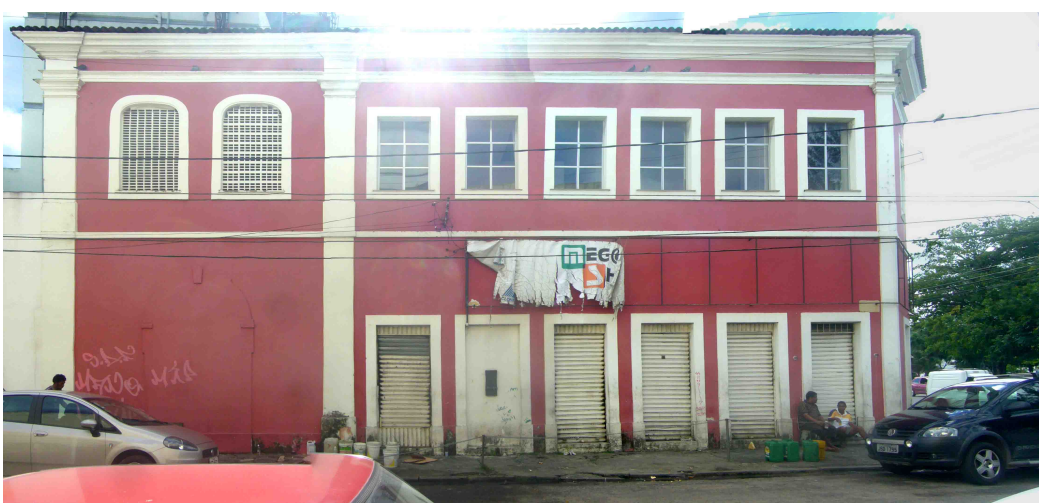

Figura 17. Indústria de Sabões Aliança Ltda. Fonte: Acervo da autora, 2012.

O conjunto da Companhia Empório Industrial do Norte (Figura 18), que teve sua construção iniciada em 1891 e recebeu diversas ampliações durante o seu funcionamento, é o patrimônio de maior destaque na Península de Itapagipe. Esta companhia teve grande destaque na produção têxtil, estando entre as maiores do Nordeste. Sofreu um incêndio no ano de 2000 que destruiu boa parte da edificação e hoje funciona como companhia aduaneira, o que gera um conflito com os usos do entorno, onde localizam-se um hospital, um asilo de idosos, escolas e residências. Podem ser ressaltados no conjunto: o grau de excepcionalidade, devido à sua vila operária, que pode ser considerada a primeira do Brasil, reflexo do pensamento do seu criador, o empreendedor Luiz Tarquínio; a distinção representativa, principalmente na monumentalidade da fachada do edifício principal da fábrica, muito bem trabalhada, apesar da perda de diversos elementos com o passar do tempo e a falta de manutenção; o tamanho e o uso, sendo este conjunto o possuidor da maior área industrial construída na península, apresentando uso, apesar de não muito adequado em parte do conjunto; esta grande área ainda apresenta a possibilidade de atração do público e turística, necessitando apenas de iniciativas que tragam um uso apropriado ao conjunto, permitindo, também, o acesso à população. Os edifícios fabris merecem um uso adequado e intervenções que não os descaracterizem. A vila operária merece ser preservada como vila, devido à composição e espaço construído, apesar da sua arquitetura se encontrar muito alterada. Sobre a companhia foram encontrados diversos escritos, todos reconhecendo a importância da fábrica e da vila operária.

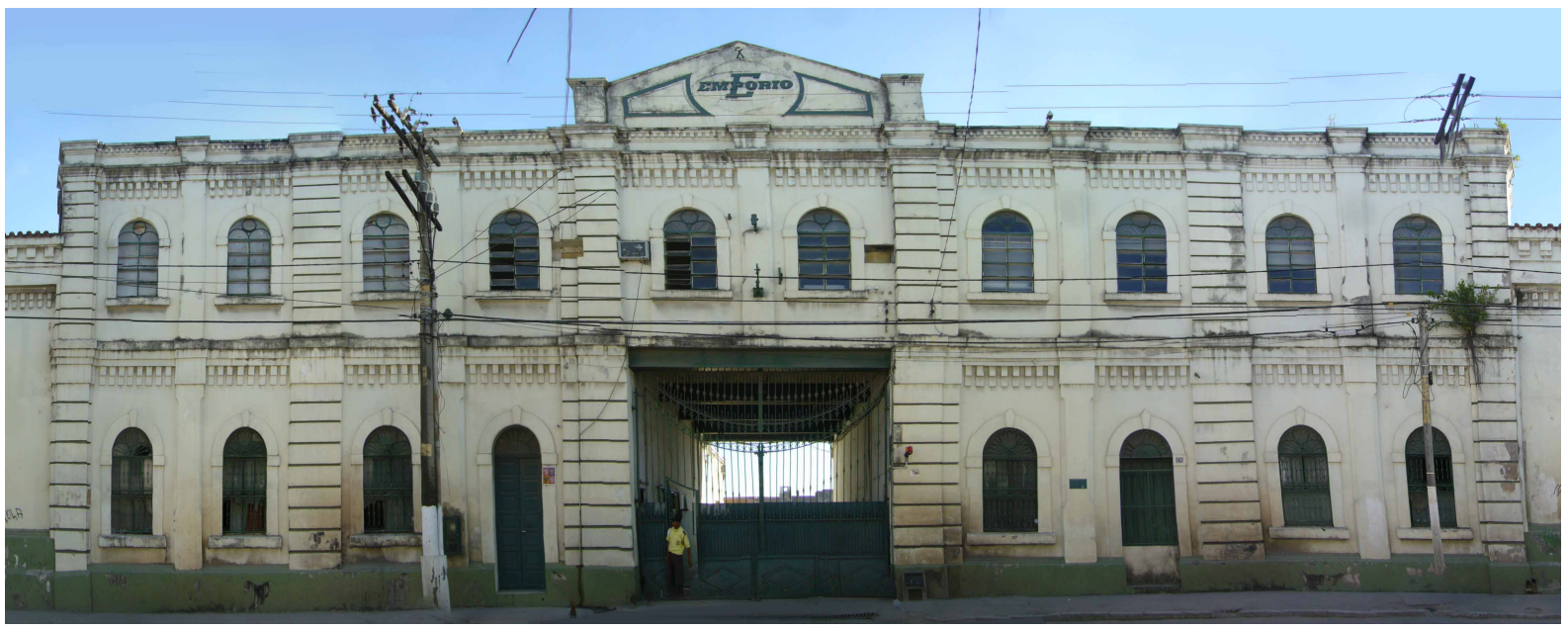

Figura 18. Companhia Empório Industrial do Norte. Fonte: Acervo da autora, 2011.

A Fábrica de Cigarros Souza Cruz (Figura 19), do ano de 1925, apresenta distinção representativa em sua arquitetura com tendências modernas, na sua simplicidade e geometria das formas. Além disso, compõe o espaço em consonância com o conjunto da Companhia Empório Industrial do Norte, apresentando possibilidade de atração do público e turística, principalmente se pensado como um grande sítio industrial, que engloba ainda a Fábrica da Leão do Norte Jurubeba. A Souza Cruz é uma das fábricas sempre referidas pelos moradores da península, estando marcada em suas memórias.

A Fábrica da Leão do Norte Jurubeba (Figura 20), que se instalou no edifício colonial no ano de 1932, marca uma das fachadas do Largo da Boa Viagem, junto com os edifícios construídos 
posteriormente que formam o conjunto. 0 conjunto apresenta distinção representativa, pela sua composição espacial e beleza, mesmo na sua simplicidade arquitetônica. Também apresenta possibilidade de atração do público e turística, já que se encontra localizada junto à Igreja da Boa Viagem, no largo de mesmo nome, e integra o sítio industrial citado anteriormente.

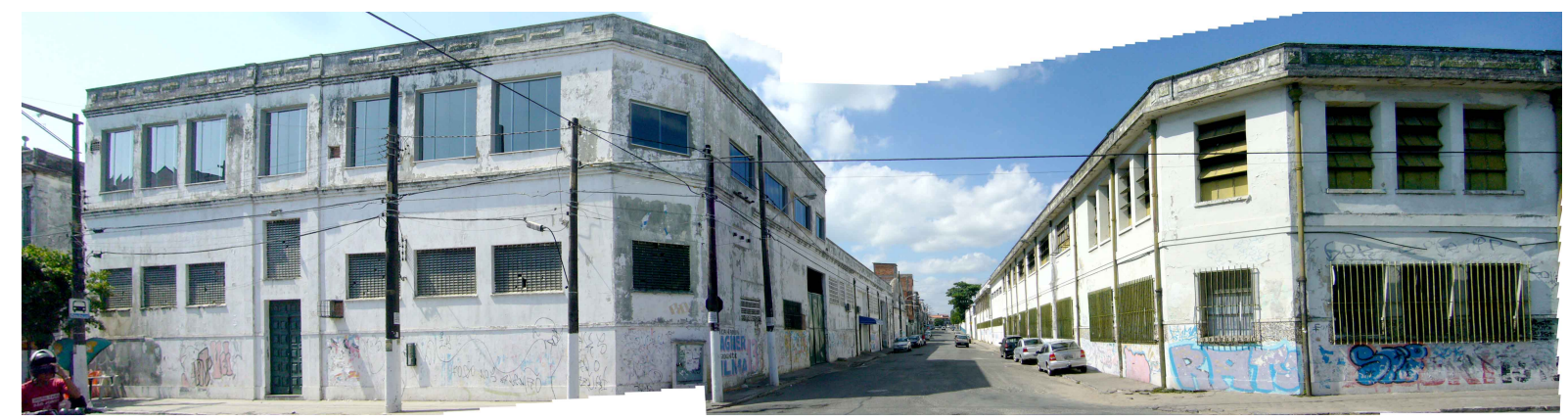

Figura 19. Fábrica de Cigarros Souza Cruz. Fonte: Acervo da autora, 2011.

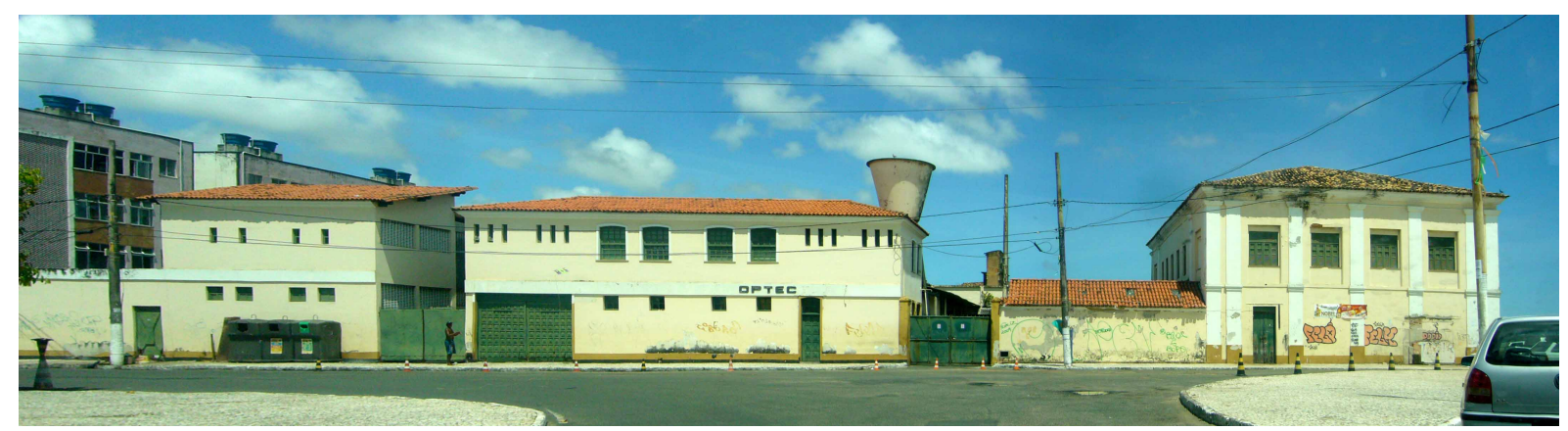

Figura 20. Fábrica da Leão do Norte Jurubeba. Fonte: Acervo da autora, 2009.

A Fábrica Sabor - Indústrias Reunidas Cítricas S/A e Fábrica de Sacos São José Ltda. (Figura 21) foram localizadas no Atlas de 1956, sendo esta a primeira referência sobre as mesmas (o levantamento para o Atlas foi realizado no ano de 1955, por isso adotado esse ano). Segundo moradores da região a fábrica de sacos fornecia embalagens para a fábrica de doces. Hoje a Cerealista Universal, empresa que trabalha com fornecimento de produtos alimentícios cereais e de bebidas cítricas, ocupa o edifício (em 2007 a Cerealista Universal já se encontrava no local). Apresenta possibilidade de atração do público, devido à sua localização, na Av. Caminho de Areia, uma das principais da região.

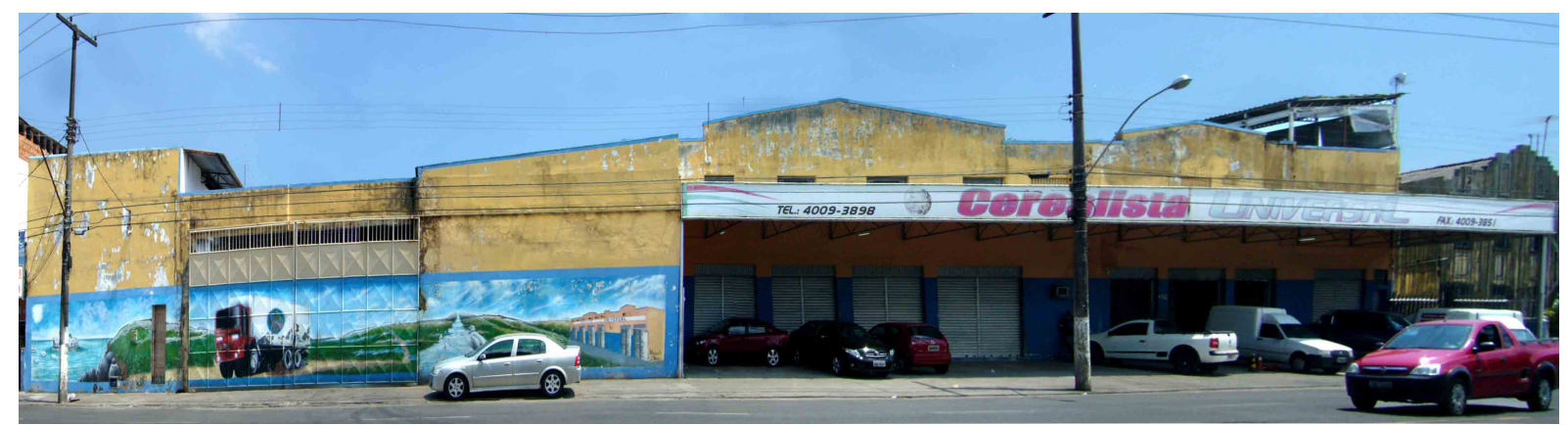

Figura 21. Fábrica Sabor - Indústrias Reunidas Cítricas S/A e Fábrica de Sacos São José Ltda. Fonte: Acervo da autora, 2011.

A Fábrica de Fibras (Figura 22) apareceu pela primeira vez nas referências no ano de 1951, no projeto da prefeitura para a passagem de ruas. A CENTRAB passou a ocupar o edifício a partir de 1989 (galpão com $4.000 \mathrm{~m}^{2}$ ), ocupando uma grande área.

A primeira referência encontrada sobre a Fábrica de Vidros de Salvador Ayres de Almeida Freitas (Figura 23) é do ano de 1904, quando foi aprovado o projeto para a construção de um barracão e um depósito destinados ao fabrico de vidro, além de levantar mais os muros do lado, frente e fundo, e caiar. Apresenta possibilidade de atração do público, devido à sua localização, em frente ao Largo da Baixa do Bonfim. 


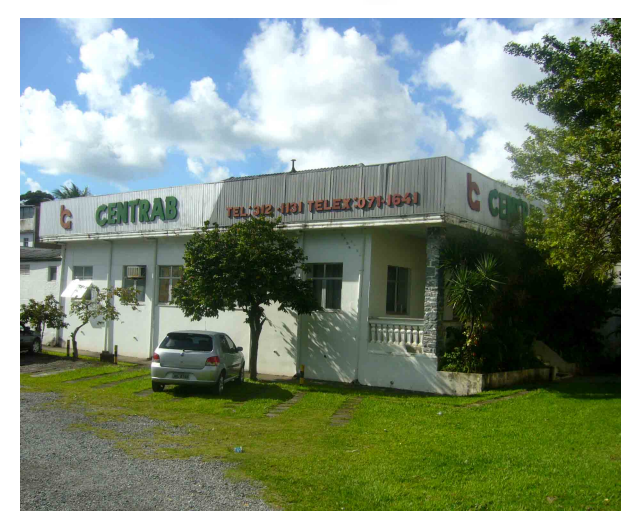

Figura 22. Fábrica de Fibras. Fonte: Acervo da autora, 2012.

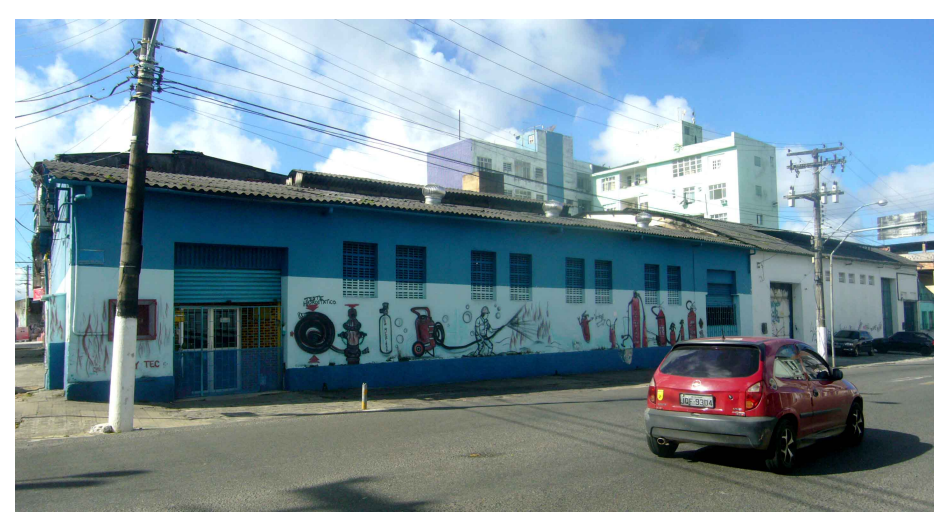

Figura 23. Indústria de Sabões Aliança Ltda. Fonte: Acervo da autora, 2012.

A Companhia Antarctica Paulista (Figura 24) ocupou o edifício no Bonfim, entre as ruas Benjamin Constant e Cosme e Moreira, atuais Ladeira do Porto do Bonfim e Rua Travasso do Meio. Esse edifício foi localizado no Atlas Parcial da Cidade do Salvador, de 1956. 0 conjunto era formado por diversos edifícios, apresentando tendências Art Déco, que podem ser observadas, principalmente, na fachada do edifício principal, apresentando uma certa distinção representativa, apesar de ter sofrido muitas perdas 59 . Ocupa uma grande área e atualmente existe uma proposta para a utilização do seu terreno para a implantação do programa "Minha casa minha vida". O conjunto provavelmente será demolido.

No ano de 1933 a Fábrica de Chocolates Bhering Companhia S/A (Figura 25) instalou-se na Av. Beira Mar (antigo Porto do Bomfim), no 18, Distrito da Penha. Foi encontrado, deste mesmo ano, o projeto de ampliação da fábrica e projeto da fachada. 0 edifício da Bhering foi ocupado em seguida pela Barretto de Araújo Produtos de Cacau S/A até, aproximadamente, 1973. 0 edifício sofreu um incêndio em 1987, no período em que servia de depósito para fardos de algodão. Abrigou também o depósito de milho da Armazéns Gerais Tazam. (Jornal Tribuna da Bahia, Caderno Cidade, 24/02/1988). 0 edifício projetava-se sobre o mar e sua estrutura encontrava-se bastante deteriorada em 2009, ano que antecede a sua demolição.

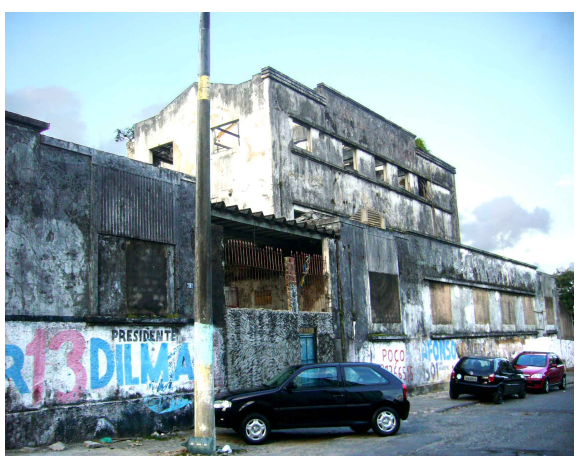

Figura 24. I Companhia Antarctica Paulista. Fonte: Acervo da autora, 2011.

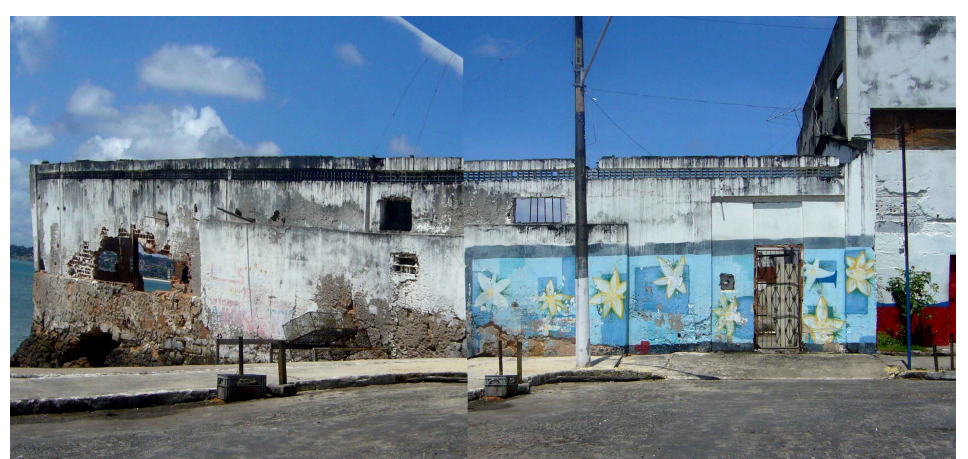

Figura 25. Fábrica de Chocolates Bhering Companhia S/A. Fonte: Acervo da autora, 2009.

A Fábrica Garcês (Figura 26) foi localizada no projeto encontrado no AHMS para loteamento de terreno do Jardim Cruzeiro, do ano de 1949, situada na Av. do Salvador (entre Avs. Tiradentes, do Salvador e Rua Thomaz Gonzaga), no Distrito de Mares. A fábrica também foi localizada no Atlas de 1956, sendo chamada de Vieira Garcês \& Cia. Ltda. Hoje o edifício é ocupado pela CODAMI. Apresenta possibilidade de atração do público, devido à sua localização, na Av. Caminho de Areia. O conjunto da Serraria Mocambo (Figura 27) é anterior ao ano de 1956, já que o levantamento do Atlas Parcial da Cidade do Salvador é do ano de 1955, porém não se pode precisar o ano da sua construção. Não foram encontradas outras informações sobre o edifício, que ocupa uma grande área.

\footnotetext{
59 Este edifício teria possibilidade de preservação. Os critérios apresentados por Buchanan (1972) apresentam certas limitações, o que dificulta ressaltar a importância de determinados exemplares.
} 


\section{Labor \& Engenho}

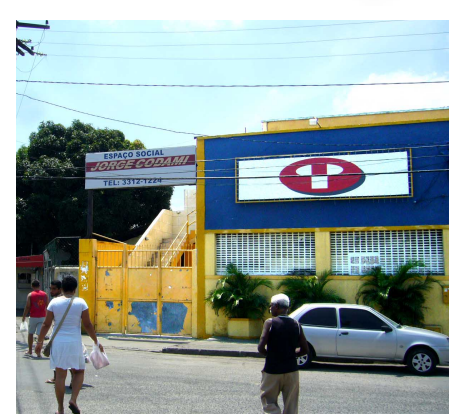

Figura 26. Fábrica Garcês.

Fonte: Acervo da autora, 2011.

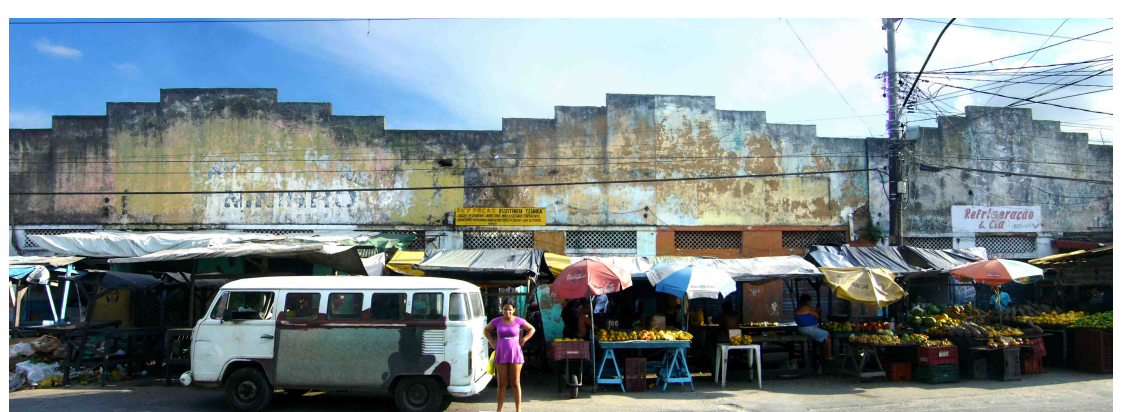

Figura 27. Serraria Mocambo. Fonte: Acervo da autora, 2011.

A primeira referência sobre este edifício é do ano de 1892, quando era ocupado pela fábrica da Companhia de Ferro Esmaltado, localizada no Largo do Papagaio. A Fábrica Paraguassú (Figura 28), que ocupou e reformou o edifício existente em 1909, expandindo o conjunto desde então, apresenta distinção representativa, devido à sua arquitetura tipicamente industrial, com grandes galpões e coberturas em arco, seguindo uma arquitetura mais moderna. 0 tamanho e o uso também são representativos nesse conjunto, já que ocupa um grande lote, com localização privilegiada, no Largo do Papagaio, e até meados de 2017 ainda abrigava o uso fabril (fábrica FAGIP). Este sítio vem sendo historicamente industrial, havendo abrigado alambique, fábrica de fumo, fábrica de louça de ferro esmaltado e fábrica de tecidos. Este uso industrial marca a região, assim como o edifício marca o Largo do Papagaio, sendo uma referência para todos que passam pela área.

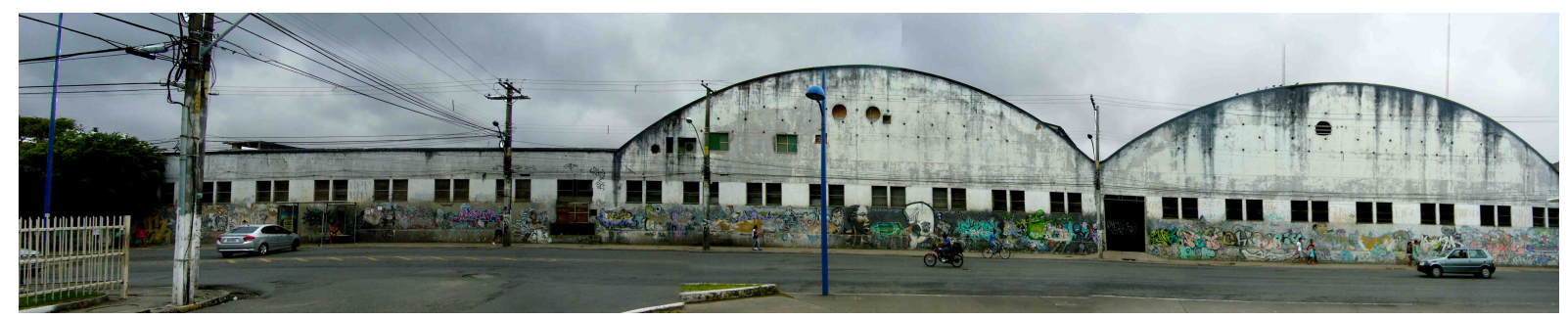

Figura 28. Fábrica Paraguassú. Fonte: Acervo da autora, 2011.

A primeira referência sobre o conjunto é que no ano de 1948 foi construído o píer em frente à fábrica, localizada à Av. Beira-Mar, hoje conhecido come ponte do Crush. Existia ali a fábrica da Monsanto (Figura 29), que construiu a ponte para escoar a sua produção de fertilizantes. Segundo fontes orais a Fábrica de Chocolate Kaufmann ocupava o edifício desde antes da década de 1950. Não foram encontradas outras referências sobre essas fábricas para esclarecer qual delas ocupava o edifício naquele período. No Atlas de 1956 o complexo industrial e o píer são encontrados. A fábrica de refrigerantes Crush ocupou o edifício na década de 1960 e deu fama ao local.

A Fábrica Saboaria Atlântica Ltda. (Figura 30) teve aprovado, no ano de 1937, o projeto para a construção do seu edifício e aparece no mapa de 1956 com o nome Atlântica Óleos Vegetais e Industrial. Segundo o funcionário da fábrica de roupas, que funciona no edifício atualmente, funcionou também no edifício uma exportadora de cacau nos anos 1960. Não foram encontradas outras informações sobre o edifício.

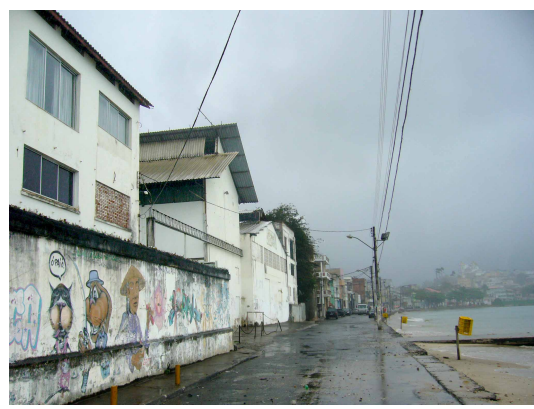

Figura 29. Fábrica Monsanto. Fonte: Acervo da autora, 2011.

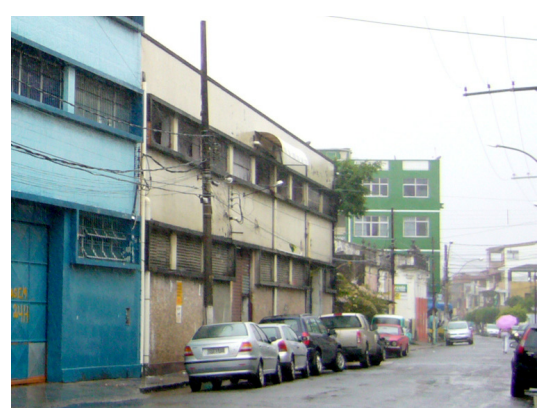

Figura 30. Fábrica Saboaria Atlântica Ltda. Fonte: Acervo da autora, 2011. 
No ano de 1955 as Indústrias Reunidas Columbia Ltda. (Figura 31) ocupavam o edifício, segundo o levantamento do Atlas Parcial da Cidade do Salvador. Não se pode precisar o ano de construção do edifício. Hoje este encontra-se dividido em duas partes, sendo a parte da frente residência e a do fundo, garagem.

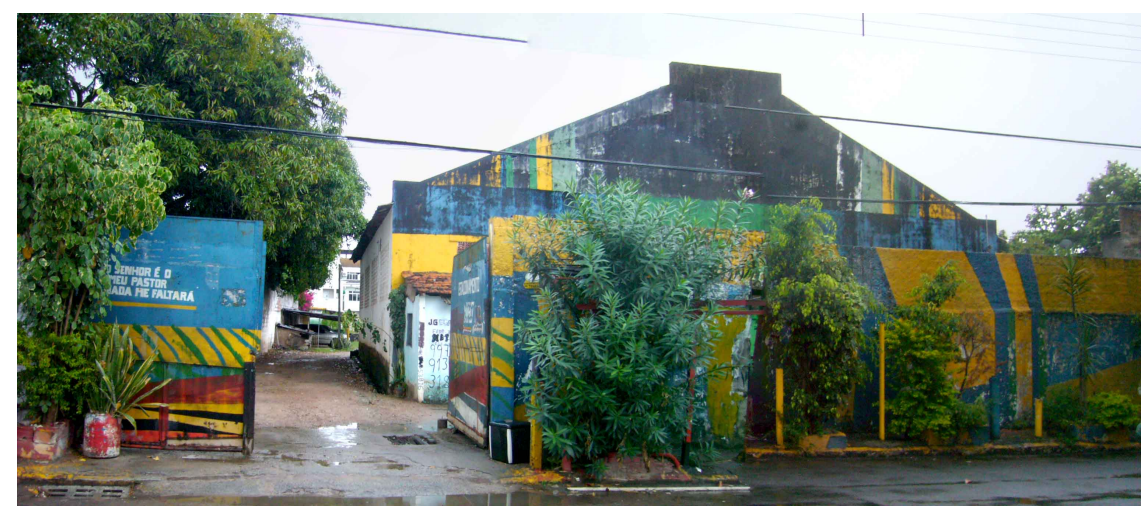

Figura 31. Indústrias Reunidas Columbia Ltda. Fonte: Acervo da autora, 2011.

A Fábrica Nossa Senhora da Penha, da Companhia Progresso e União Fabril da Bahia (Figura 32), do ano de 1873, é a segunda mais antiga indústria remanescente na península. Ao contrário da Fábrica da Conceição, esta ainda se encontra em estado de conservação razoável, o que lhe permitiria uma conservação que visasse a melhoria do seu estado de conservação e a recepção de um novo uso. Sua chaminé é a única que permanece na região (de todos os edifícios estudados), marcando o espaço, apresentando grau de excepcionalidade. Reconhecemos no conjunto também: a distinção representativa na composição dos espaços e na própria arquitetura eclética, apesar de simples, do edifício principal do conjunto; o tamanho e uso, por ocupar um grande lote na Ribeira e ter uso parcial. 0 edifício principal não apresentaria problemas para receber um novo uso, devido às suas dimensões e amplitude dos espaços. É reconhecida ainda a possibilidade de atração do público e turística, por estar localizado em um local privilegiado para o uso turístico (que poderia ser potencializado com algum investimento). Sua importância é local, para a história e arquitetura da cidade de Salvador e, principalmente, para a história da região da Ribeira, sendo um edifício referência naquela área.

O conjunto da Companhia de Navegação Bahiana (Figura 33), construído a partir de 1948, apresenta grau de excepcionalidade, por ser o remanescente mais antigo das companhias de navegação da península. Existe possibilidade de atração do público e turística, principalmente devido à sua localização, próxima ao Largo da Ribeira, à Igreja da Penha, à praia da Ribeira, à Marina, a diversos bares e à Fábrica Nossa Senhora da Penha. 0 edifício marca o período em que a Ribeira era um ponto disputado por essas companhias devido à sua localização privilegiada. No entre finais de 2017 e início de 2018 passava por obras que descaracterizavam parte do conjunto.

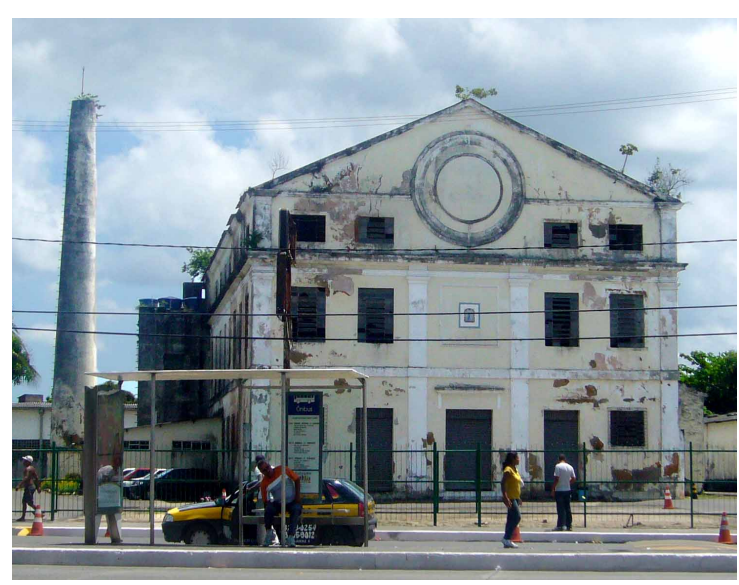

Figura 32. Indústria de Sabões Aliança Ltda. Fonte: Acervo da autora, 2009.

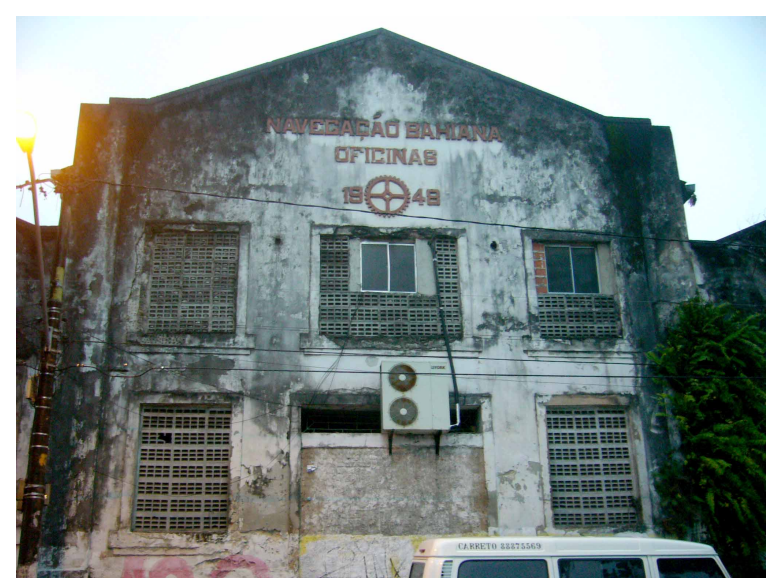

Figura 33. Indústria de Sabões Aliança Ltda. Fonte: Acervo da autora, 2011. 
Desta forma, pode-se sintetizar uma proposta para a preservação dos edifícios industriais da Península de Itapagipe de acordo com a Tabela 1.

Tabela 1. Exemplares da arquitetura industrial da Península de Itapagipe sugeridos para a preservação, por ano, destacando-se os critérios utilizados para a seleção. Fonte: Acervo da autora, 2012.

\begin{tabular}{|lcl|}
\hline \multicolumn{1}{|c|}{ Edifício } & Ano & \multicolumn{1}{c|}{ Critérios de Seleção } \\
\hline Fábrica da Conceição & 1835 & Grau de excepcionalidade. \\
\hline Estação da Calçada & 1861 & $\begin{array}{l}\text { Grau de excepcionalidade; distinção representativa; tamanho e uso; } \\
\text { possibilidade de atração do público e turística; e suporte local. }\end{array}$ \\
\hline Fábrica Nossa Senhora da Penha & 1873 & $\begin{array}{l}\text { Grau de excepcionalidade; distinção representativa; tamanho e uso; e } \\
\text { possibilidade de atração do público e turística. }\end{array}$ \\
\hline Fábrica da União Fabril dos Fiaes & 1890 & Tamanho e uso; e possibilidade de atração do público ou turística. \\
\hline $\begin{array}{l}\text { Conjunto da Companhia Empório } \\
\text { Industrial do Norte }\end{array}$ & 1891 & $\begin{array}{l}\text { Grau de excepcionalidade; distinção representativa; tamanho e uso; e } \\
\text { possibilidade de atração do público e turística. }\end{array}$ \\
\hline Companhia Carris Elétricos & 1897 & $\begin{array}{l}\text { Grau de excepcionalidade; tamanho e uso; e possibilidade de atração do } \\
\text { público e turística. }\end{array}$ \\
\hline Fratelli Vita & 1902 & $\begin{array}{l}\text { Distinção representativa; tamanho e uso; e possibilidade de atração do } \\
\text { público e turística }\end{array}$ \\
\hline Fábrica Paraguassú & 1909 & Distinção representativa; e tamanho e uso. \\
\hline $\begin{array}{l}\text { Fábrica de Cigarros dos Srs. } \\
\text { Guimarães André \& Cia. }\end{array}$ & 1919 & Possibilidade de atração do público e turística; e suporte local. \\
\hline Souza Cruz & 1925 & Distinção representativa; e possibilidade de atração do público e turística. \\
\hline Leão do Norte & 1932 & Distinção representativa; e possibilidade de atração do público e turística. \\
\hline Companhia de Navegação Bahiana & 1948 & Grau de excepcionalidade; e possibilidade de atração do público e turística. \\
\hline
\end{tabular}

Como pode ser observado, de todos estes edifícios 30 edifícios listados, apenas a Fratelli Vita foi tombada pelo IPAC (Tombamento Estadual - Decreto no. 8.357/2002), não existindo edifícios tombados pela Federação (IPHAN) ou pelo Município (Fundação Mário Leal Ferreira). 0 reconheci-mento de grande parte dos edifícios identificados como relevantes neste trabalho já existe, como pode ser observado no relatório do Plano Referencial de Desenvolvimento Sustentável da Península de Itapagipe - PRDI, de 2008, que destaca as antigas fábricas Barreto de Araújo, Fratelli Vita, Souza Cruz e Empório Industrial. Segundo este plano as estruturas de antigas fábricas e depósitos encontram-se, majoritariamente, em degradação e a espera de projetos que lhes deem nova utilização (Cammpi \& Nai, 2008). O PRDI contou com a participação de diversas Secretarias, Fundações, Associações de moradores da região, etc., visando, neste plano, a valorização do fator humano, infraestrutura e serviços, diversidade econômica produtiva e organização e gestão do espaço urbano, buscando melhoria da qualidade de vida da população local. 0 patrimônio edificado também se insere neste plano, com vistas ao "desenvolvimento de projetos de conservação e reutilização do patrimônio edificado de valor histórico como outros que se encontram em processos de degradação" (Cammpi \& Nai, 2008, p. s/n). 0 plano reconhece o patrimônio industrial como parte relevante do patrimônio histórico da região.

Neste processo de saída das indústrias da região e mudança de caráter da mesma, a península itapagipana foi ganhando certo ar de abandono e as populações menos favorecidas convergiram para ela pela facilidade de compra dos imóveis (devido à desvalorização da área e os baixos preços dos terrenos e imóveis) e pela proximidade do centro comercial da cidade baixa. Esta é a situação encontrada por muitos anos na área.

Além de todas as situações desfavoráveis à manutenção deste patrimônio, neste momento, os grandes interesses imobiliários convergem seus olhares para península, com a finalidade de dar "nova vida" à região, especialmente as partes litorâneas, que estão cada dia mais visadas. Com estes interesses da iniciativa privada em foco, a necessidade de conhecer e atuar sobre o patrimônio desta região torna-se ainda maior, já que corremos o risco de perdê-lo. 


\section{Conclusão}

Os vestígios deixados pelo período industrial na Península de Itapagipe apresentam grande e inquestionável importância por seus valores históricos, sociais, arquitetônicos, econômicos, culturais, tecnológicos, etc., demonstrando, assim, grande importância e interesse para o estudo e a preservação.

Pode-se observar que a sua preservação não se distancia das práticas vigentes na Bahia e, ousaria dizer, no Brasil. Nosso patrimônio industrial ainda não tem o reconhecimento suficiente para suscitar a mobilização popular e a preservação dos seus exemplares, estando sujeito a constantes perdas, como pudemos observar, com pouquíssima ou nenhuma mobilização. Talvez o seu reconhecimento chegue quando este patrimônio estiver quase que completamente perdido, porém devemos nos mobilizar para que isto não ocorra.

É importante ressaltar que o patrimônio industrial é tão relevante quanto qualquer outro patrimônio cultural, e deve ser visto como tal, e as ações sobre ele devem ser coerentes com as preservacionistas. Um ponto positivo para a possível salvaguarda deste patrimônio na Península de Itapagipe e, de certa forma, na Bahia, é que ainda podemos encontrar muitos remanescentes, fator muito favorável para a seleção e preservação pelo menos dos exemplares mais significativos. Destaca-se aqui a importância da abordagem teórica das questões relativas à arqueologia e ao patrimônio industrial, que são fundamentais para a definição do campo de trabalho e o entendimento sobre a arquitetura industrial e seus valores para a preservação.

Estudos interdisciplinares devem ser desenvolvidos, levando em consideração, além dos fatores materiais, os valores imateriais, já que muitas pessoas tem uma relação direta ou indireta com as indústrias, seja trabalhando nelas ou percebendo-as em seu cotidiano.

Para entender a relevância da indústria na vida da população, traz-se um exemplo bastante recente. 0 Polo Industrial de Camaçari completou 40 anos no dia 29 de junho de 2018 e o Jornal A Tarde dedicou dois cadernos para falar da sua importância para o desenvolvimento da cidade de Camaçari e seu entorno. Este fator, por si só, mostra a importância das indústrias na vida das populações das áreas industriais, reforçando a necessidade da preservação dos exemplares mais representativos, mesmo quando os mesmos já não atendam a função industrial.

\section{Referências}

Andrade Junior, N. V. (2011). Do Ouro Branco ao Ouro Negro: as políticas públicas de preservação do patrimônio industrial na Bahia. Revista Eletrônica Urbana, 3. Acesso em 30 de jan de 2018, disponível em https://periodicos.sbu.unicamp.br/ojs/index.php/urbana/article/view/8635127/2942

Arquivo Noronha Santos. Acesso em 30 de jun de 2018, disponível em http://www.iphan.gov.br/ans.net

Azevedo, E. B. (2010). Patrimônio industrial no Brasil. usjt - arq.urb, 3. Acesso em 30 de jun de 2018, disponível em http://www.usjt.br/arq.urb/numero_03/2arqurb3-esterezilda.pdf

Bristol Industrial Archaeological Society. Acesso em 27de jun de 2018, disponível em www.b-i-a-s.org.uk

Buchanan, R. A. (1972). Industrial Archaeology in Britain. Harmondsworth (GB): Penguin.

Cammpi, \& Nai. (2008). Plano Referencial de Desenvolvimento Sustentável da Península de Itapagipe (PRDI). Salvador.

Cardoso, C. R. (2004). Arquitetura e Indústria: a península de Itapagipe como sítio industrial da Salvador Moderna (1892-1947). Dissertação de Mestrado em Teoria e História da Arquitetura, Universidade de São Paulo, Departamento de Arquitetura e Urbanismo, Escola de Engenharia de São Carlos, São Carlos, SP, Brasil.

Comitê Brasileiro para a Preservação do Patrimônio Industrial TICCIH - Brasil. Acesso em 27 de jun de 2018, disponível em www.patrimonioindustrial.org.br

Council for British Archaeology. Acesso em 17 de jun de 2018, disponível em new.archaeologyuk.org

Falconer, K. (2006). The industrial heritage in Britain - the first fifty years. La revue pour l'histoire du CNRS [Online](14). Acesso em 17 de Junho de 2018, disponível em http://histoire-cnrs.revues.org/1778 
Fonseca, M. C. (2005). O patrimônio em processo: trajetória da política federal de preservação no Brasil (2 ${ }^{\text {a }}$ ed. rev. ampl. ed.). Rio de Janeiro: Editora UFRJ / Minc - IPHAN.

García García, D. A., \& Rivas Badillo, N.-H. (2007). Usos turísticos del patrimonio industrial ferroviario en la ciudad de Puebla. Dissertação de Mestrado em Administración de Hoteles y Restaurantes, Universidad de las Américas Puebla, Cholula, Puebla, México, Departamento de Turismo, Escuela de Negocios y Economía, Cholula.

Gomes, N.D. (2007). Inventário do Patrimônio Industrial Têxtil na Península de Itapagipe - Salvador - BA. Trabalho de Conclusão de Curso da Graduação em História com concentração em Patrimônio Cultural, Universidade Católica do Salvador.

Hudson, K. (1979). World Industrial Archaeology. Londres: Cambridge University Press.

IPAC. Acesso em 30 de jun de 2018, disponível em patrimonio.ipac.ba.gov.br/

Jokilehto, J. I. (1999). History of Architectural Conservation. Oxford: Butterworth-Heinemann.

Kühl, B. M. (2008). Preservação do Patrimônio Arquitetônico da Industrialização: Problemas teóricos do restauro. Cotia: Ateliê Editorial.

Kühl, B. M. (2010). Patrimônio industrial: algumas questões em aberto. Revista arq.urb, 3, pp. 23-30. Acesso em 24 de Jun de 2018, disponível em http://www.usjt.br/arq.urb/numero_03/3arqurb3-beatriz.pdf

Luther, A. C. (2012). Patrimônio Arquitetônico Industrial da Península de Itapagipe: um estudo para a preservação. Dissertação de Mestrado, Universidade Federal da Bahia, Faculdade de Arquit. e Urbanismo, Salvador, BA, Brasil.

Meneguello, C. (2006). The Industrial Heritage in Brazil and prospects for the Brazilian Committee for the Conservation of Industrial Heritage. Anais do XIII International Congress of The International Committee for the Conservation of the Industrial Heritage (TICCIH). Roma.

Meneguello, C. (2011). Patrimônio industrial como tema de pesquisa. Anais do I Seminário Internacional História do Tempo Presente. Florianópolis: UDESC, ANPUH-SC, PPGH. Acesso em 30 de jun de 2018, disponível em http://eventos.udesc.br/ocs/index.php/STPII/stpi/paper/viewFile/313/234

Mota, L. G. (2009). A arquitetura fabril na Bahia: um patrimônio desconhecido. Anais II Encontro Nacional sobre Patrimônio Industrial. São Paulo: Centro Universitário Belas Artes de São Paulo.

Rodrigues, M. (2010). Patrimônio industrial, entre o fetiche e a memória. Arq.Urb: Revista Eletrônica de Arquitetura e Urbanismo, 3. Acesso em 30 de jun de 2018, disponível em http://www.usjt.br/arq.urb/ numero_03/4arqurb3-marly.pdf

Rufinoni, M. R. (2004). Patrimônio Histórico Industrial na Cidade de São Paulo. Dissertação de Mestrado em Arquitetura e Urbanismo, Universidade de São Paulo, Faculdade de Arquitetura e Urbanismo, São Paulo.

Rufinoni, M. R. (2014). Patrimônio Histórico Industrial na Cidade de São Paulo. Dissertação (Mestrado em Arquitetura e Urbanismo), Faculdade de Arquitetura e Urbanismo, Universidade de São Paulo, São Paulo.

Santos, N. P. (2009). A fábrica de ferro São João de Ipanema: economia e política nas últimas décadas do Segundo Reinado (1860-1889). Dissertação (Mestrado em História Econômica), Universidade de São Paulo, FFLCH, São Paulo, SP, Brasil. Acesso 30 jun. 2018, disponível em http://www.teses.usp.br/teses/disponiveis/8/8137/ tde-09122009-094712/pt-br.php

The Greater London Industrial Archaeology Society. Acesso em 27 jun. 2018, disponível em www.glias.org.uk

The Manchester Region Industrial Archaeology Society. Acesso em 27 de jun de 2018, disponível em www.mrias.co.uk

The Society for Industrial Archeology. Acesso em 27 de jun de 2018, disponível em www.sia-web.org

TICCIH. (2003). Carta de Nizhny Tagil sobre o patrimônio industrial. TICCIH. Acesso em 30 de jun de 2018, disponível em http://ticcih.org/wp-content/uploads/2013/04/NTagilPortuguese.pdf

Unicamp (1998). Carta de Campinas: Declaração do GEHT em defesa das construções e instalações utilitárias. Acesso 06 fev. 2012, disponível em https://cordiolli.files.wordpress.com/2011/06/declara-geht-carta-de-campinas.pdf

Vichnewski, H. T. (2004). As indústrias Matarazzo no interior paulista: arquitetura fábril e patrimônio industrial (1920-1960). Dissertação (Mestrado em História), Universidade Estadual de Campinas, Campinas, SP, Brasil.

Viterbo, F. M. (1896). Archeologia Industrial Portuguesa. Os Moinhos. (I. Nacional, Ed.) Arqueólogo Português, II (8 e 9), 193-204. 